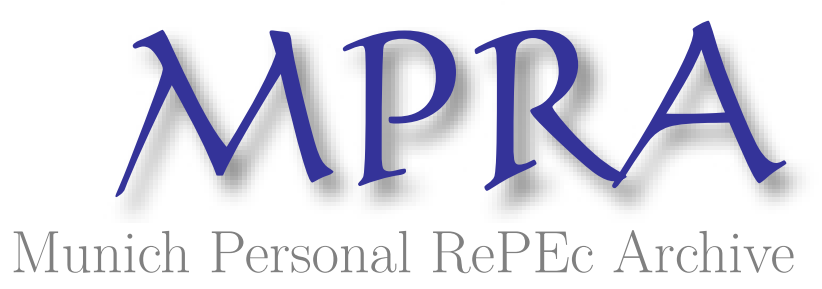

\title{
Economic Freedom and Economic Performance: Does Good Governance Matter? The Case of APAC and OECD Countries
}

Emara, Noha and Reyes, Loreto

16 October 2020

Online at https://mpra.ub.uni-muenchen.de/103590/

MPRA Paper No. 103590, posted 21 Oct 2020 15:43 UTC 


\title{
Economic Freedom and Economic Performance: Does Good Governance Matter? The Case of APAC and OECD Countries
}

\author{
Noha Emara ${ }^{a_{1}}$, Loreto Reyes Rebolledo \\ a \\ Associate Professor, Rutgers University and SIPA, Columbia University, USA \\ $\mathrm{b}$ \\ Columbia University, USA
}

\begin{abstract}
Economic freedom is an important determinant of economic growth and income distribution, which are key factors in facilitating economic development. The paper empirically investigates the relationship between economic freedom and economic performance in the APAC and OECD countries. A panel model with fixed effects technique is employed on yearly data for the period 1980-2017, using a number of measures of economic freedom covering the size of government, property rights, monetary policy, access to international trade, and regulation of credit labor, and businesses. The study also investigates the role of governance in affecting the impact of economic freedom on economic performance. The results of the study indicate that economic freedom positively affects economic performance in the selected countries after controlling for country-and time- fixed-effects. Additionally, the study finds that this positive impact is higher for the APAC than for the OECD countries. For APAC countries, a country's size of government, expansionary monetary policy, and less regulation has a positive and statistically significant impact on its output per worker. Finally, the study finds that governance is a pre-condition for economic freedom, where the impact of economic freedom on economic performance is amplified by about five folds in the presence of better governance including the freedom of a country's citizens in selecting governments and expressing their political views, political stability, enhanced quality of public services, and control of corruption.
\end{abstract}

JEL Classification Numbers: O16; O43; N20

KEYWORDS: APAC; OECD; Economic Freedom; Panel Models; Governance

${ }^{1}$ Corresponding author. Email: nemara@camden.rutgers.edu,ORCID: https://orcid.org/0000-0002-7981-8256. 


\section{Introduction}

Economic development has been a significant topic of economic research because of how many factors influence it. A major source of economic development comes from a country's level of output per worker. The determinants of output per worker have also been studied immensely as countries have evolved and scaled their economies, however there are still some areas that remain underdeveloped. As countries have developed on varying timelines with different resources and infrastructure, it raises the question as to what enabled the development. As research on economic development has increased, many factors have been revealed to play a very important role. In more recent years, one of those factors has been said to be the level of economic freedom within a nation.

Existing literature reveals that economic performance is positively correlated with the level of economic freedom within a country (Miller and Kim, 2017). This is one of the major reasons that there has been an emphasis on implementing policies that encourage economic freedom globally. Regionally, there have been differences in how economic freedom plays a role in a country's development. As a result, there is a need to discover what factors influence the difference that exists between regions and within regions.

Asia-Pacific, or APAC, is an interesting case study for the concept of economic freedom. APAC contributes to most of the world's population and has a wide spread of economic levels throughout the region. Some of the world's most free economies such as Hong Kong and Singapore as well as the world's least free economies such as North Korea and Afghanistan reside in APAC (Miller and Kim, 2017). As a result of the large disparity between levels of economic freedom, APAC provides an opportunity to explore how economic freedom differs between countries. In addition to APAC, The Organization for Economic Co-operation and Development (OECD) provides a different opportunity to explore the dynamic of economic freedom within regions. OECD focuses on building better policies for better lives by working with governments, policy makes, and citizens to establish evidence-based international standards and find solutions to a range of issues, (OECD, 2020). One of their focuses is increasing economic freedom globally and have done so within their active member countries. As a result, there is less

of a disparity in levels of economic freedom between OECD countries because they 
implement and share similar policies and perspectives. Because APAC and OECD have different relationships with economic freedom we can compare the two in order to analyze the components of a country that impact its level of economic freedom and how that then impacts the output per worker.

\section{Figure (1): Evolution of Economic Freedom-- APAC, OECD, and the World}

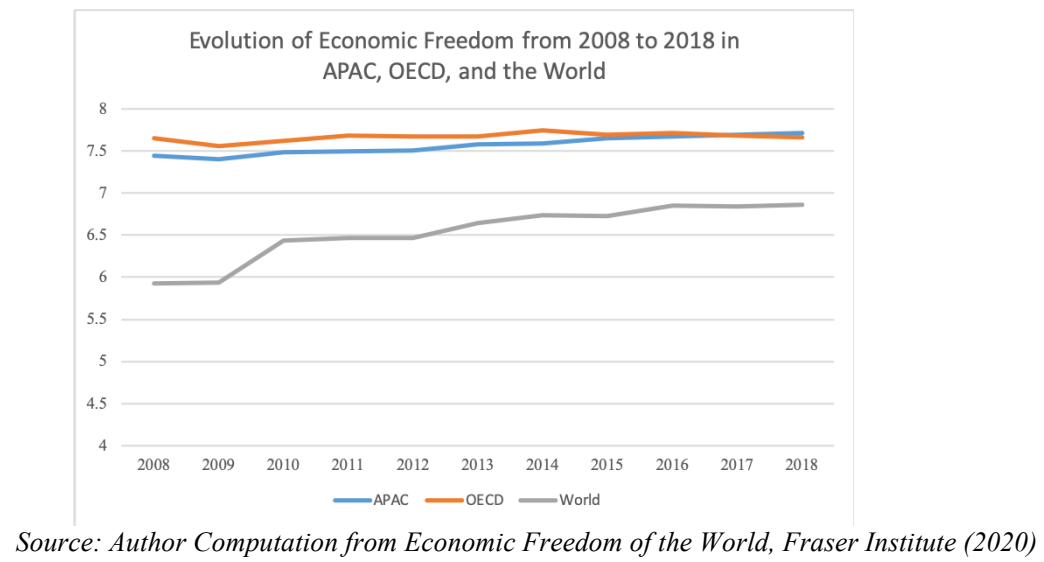

On the one hand, since OECD focuses on implementing policies that improve economic freedom, their levels of economic freedom as a collective tend to be higher than other regions as well as the world as a whole. On the other hand APAC countries do also tend to have a higher average than the world, this is because of the varying extremes of levels of economic freedom within the region which are pulled higher because of the most free countries and pulled down because of the least free countries. The Fraser Institute is a Canadian based research organization that has studied economic freedom globally since the 1970s and has produced an annual report since 1996. The Fraser institute takes the determinants of economic freedom which have generally been considered as legal systems, government size, economic regulation, and market openness, and create a score from 1-10 to determine the overall level of economic freedom. As expected, OECD countries score slightly higher than APAC countries, most likely due to their focus on increasing economic freedom. Since 2008 the level of economic freedom in the world has increased significantly; in 2008 the world scored 5.92 which would be considered as least free (as it would fall into the 4th quartile of the dataset). However, in 2018 the world scored 6.86 which is in the 3rd quartile, but close to the 2nd quartile which consists of countries that have scored higher than 7 (figure 1). This increase 
globally is most likely due to an increase in global organizations that focus on implementing policy that increases economic freedom.

In recent years, many global financial organizations have begun to prioritize economic freedom. The World Bank and International Monetary Fund (IMF) are two primary global organizations that emphasize improving economic conditions through holistic policy changes. The World Bank aims to reduce financial and technical challenges that countries face globally through development projects. Their current projects fall into the following categories: Economic Policy, Environment and Natural Resource Management, Finance, Human Development and Gender, Private Sector Development, Public Sector Management, Social Development and Protection, and Urban and Rural Development (The World Bank, 2020). The IMF's main goal is to ensure stability of an international monetary system. Similarly, to The World Bank, IMF does so through projects that fall under the following categories: Climate Change, Fintech, Fiscal Issues, Gender, Low-Income Countries, and Sustainable Development Goals (SDGs) (IMF, 2020). Research released in 2002 revealed that there was no clear relationship between the IMF's programs and economic freedom, but that there was a positive relationship between the World Bank's projects and economic freedom (Boockmann and Dreher, 2002). This positive relationship helps explain the significant increase in economic freedom in the world seen in figure 1. In terms of the lack of a clear relationship between the IMF's projects and economic freedom, it is important to realize how much their projects have changed since 2002 and there might have been a change in the relationship between the two. This is especially important because the research paper revealed that the impact of the World Bank's projects on economic freedom was stronger in the 1990s than any other decade before. So, if that trend were to continue, the relationship would be stronger as time continues, and the IMF's projects would most likely also gain a positive relationship with economic freedom. If this is true, these developing countries would be able to make significant economic progress with the aid of organizations that prioritize economic freedom.

Economic freedom provides the opportunity to produce economic growth and make income distribution more equal (Berggren, 2003). Economic growth and income distribution are key factors that can facilitate economic development for developing 
countries. Income inequality tends to be more of an issue for developing countries than developed countries (Santacreu, 2017), which is why developing countries specifically can benefit from increased economic freedom. However, this is not usually the case-developing countries tend to struggle with the components of economic freedom such as having proper legal systems, property rights, access to a free market, etc. For example, judicial effectiveness, which is one of the tenets of legal systems, is crucial to laying the foundation for economic growth in a developing country (Miller and Kim, 2017). Unfortunately, this is not always possible because of the systems that tend to be placed in developing countries which typically do not protect their citizens and their rights. In fact, data from analysis of APAC countries shows that APAC countries struggle with the legal systems and market openness components despite outperforming the world in government size and economic regulation components (figure 2).

Figure (2): Scores Economic Freedom Determinants and their Factors for APAC and the World (2017)

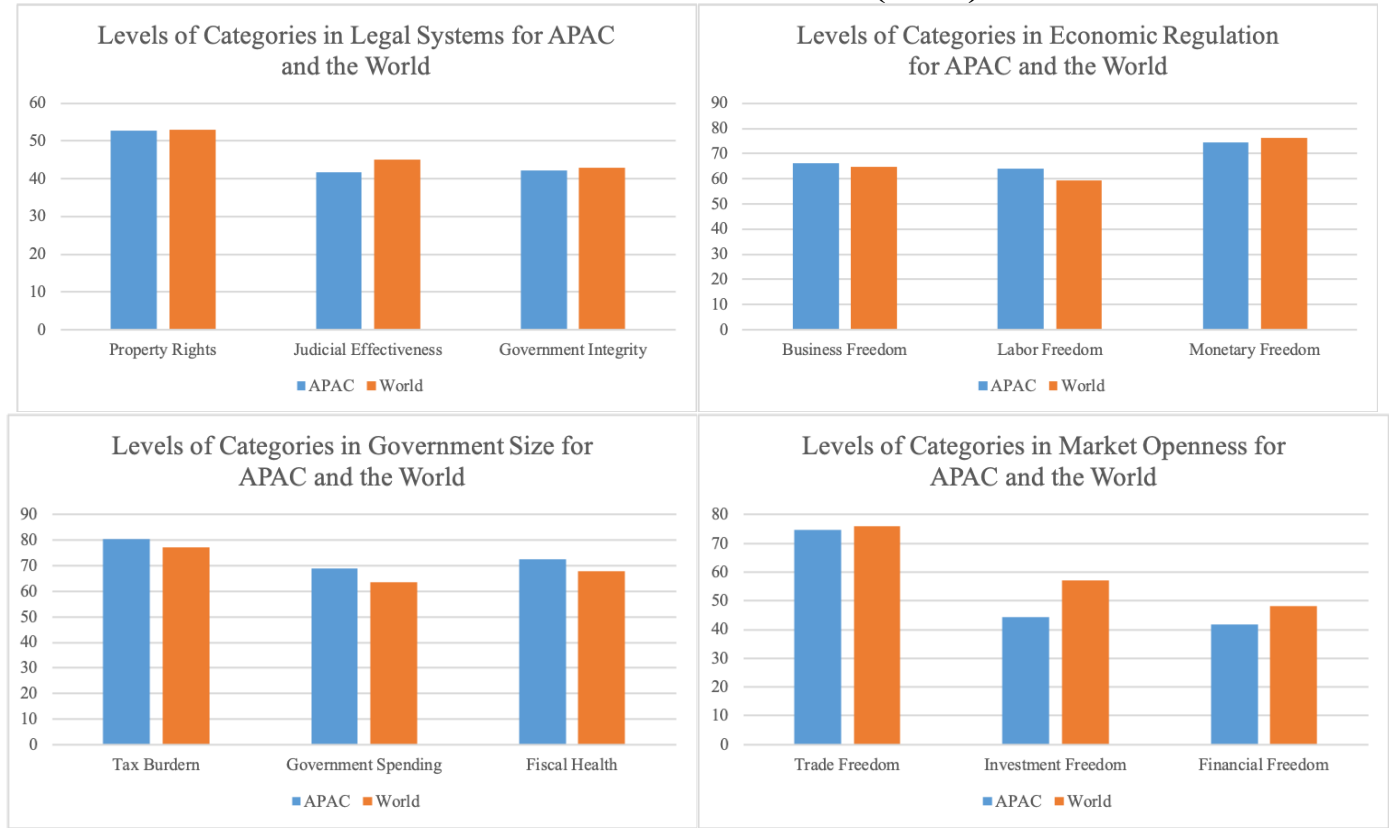

Source: Author computation using Index of Economic Freedom data for 2017.

After discussing levels of economic freedom in APAC and OECD countries, it is also important to discuss their levels of output per worker as the goal of this paper is to understand the relationship between economic freedom and output per worker. Using GDP per worker as a measure of output per worker indicates that OECD countries have 
significantly higher output per worker than APAC countries. However, APAC countries have shown higher levels of growth in output per worker; in 2008 their output per worker was $\$ 20,497.42$ but grew to $\$ 32,654.13$ in 2018. OECD countries had an output per worker of $\$ 88,014.20$ in 2008 and $\$ 94,120.94$. OECD countries saw an almost a $7 \%$ increase in output per worker over a 10 year period while APAC countries saw an almost $60 \%$ increase (figure 3 ).

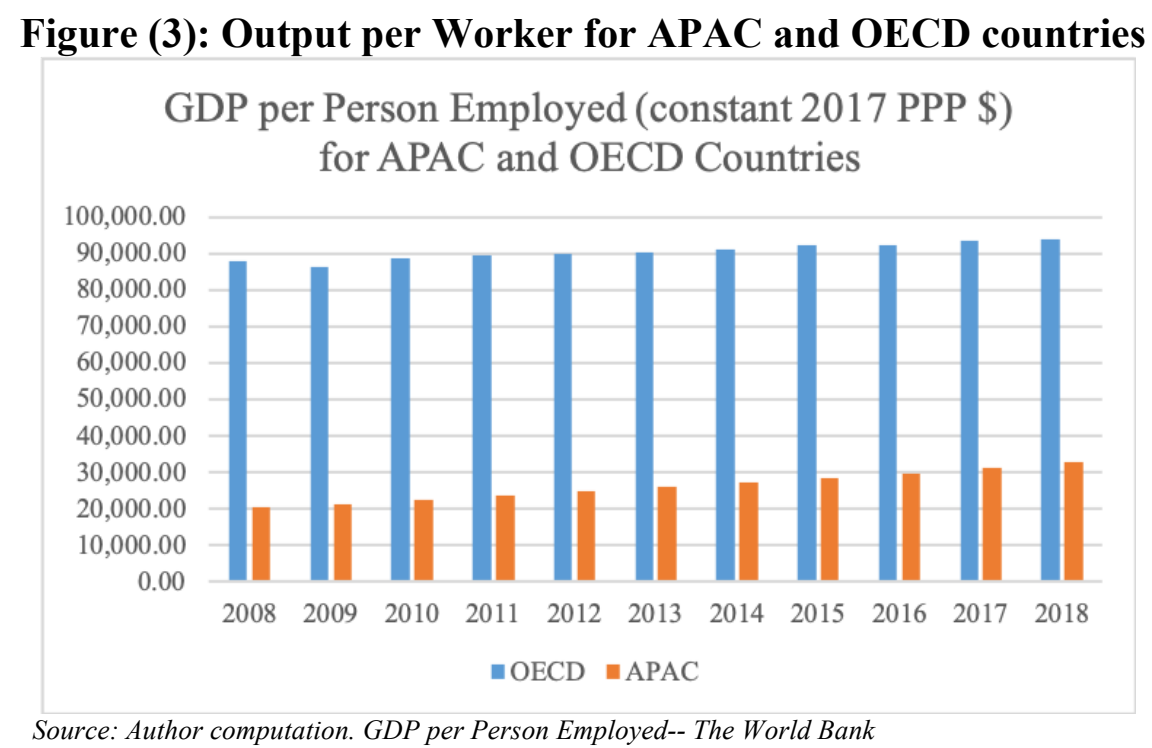

While there is a vast amount of literature that confirms the positive relationship between economic freedom and economic growth, there are other aspects of a country that must also play a role in its economic development. In particular, different regions, and even countries within the same region, have different infrastructure such as government size, access to social and financial services, and perspective on trade. The infrastructure a country has, has proved to be significant, especially to developing countries. It is clear that economic freedom does facilitate the economic development of a nation, and its extent relies heavily on the infrastructure of a nation.

Nonetheless, the link between the improvement in measures of economic freedom on economic performance and the impact of good governance on such a link has been understudied. Given the importance of this relationship, the study contributes to the literature by filling the gaps and analyzing how economic freedom helps in improving 
economic performance and how better levels of governance affect this impact of economic freedom. More specifically, the study will attempt to answer several questions: Which types of economic freedom affect economic performance? Is the effect the same across the two regions; APAC and OECD? How the improvement in governance measures affects the impact of economic freedom on economic performance? The rest of the paper is organized as follow. Section 2 provides a review of the literature. Sections 3 and 4 present the data used and the methodological approach, respectively. Section 5 presents our estimation results. Finally, Section 6 concludes. The appendix is by the end of the paper.

\section{Literature Review}

Existing literature has empirical evidence that countries with higher levels of economic freedom exhibit better economic performance. Economic performance can be defined in various ways, however in this context economic performance is defined as economic development. Due to the various levels of economic development throughout the world, a lot of research has also been conducted to study the relationship between economic freedom and economic development. In particular, Hann and Sturm (1999) compared two economic freedom indices to determine the extent to which the countries they include have similar ranking and if there is an empirical relationship between a country's level of economic freedom and level of economic development. They compared the economic freedom indices from the Fraser Institute and the Heritage Foundation-- two organizations that have reported on global levels of economic freedom for decades. Hann and Sturm concluded that the indices are consistent between the two organizations and that there is a positive relationship between economic freedom and output per worker. However, a significant conclusion they made was that variations in economic freedom impact a country's economic growth, while the level of economic freedom is unrelated to economic performance. Hall and Jones (1999) researched the disparity in output per worker between countries. Through an analysis of a sample of 127 countries, they found that there is a positive relationship between a country's economic performance and it's institutional characteristics. In their study they measure economic performance as capital 
accumulation, human capital, and total factor productivity and define institutional characteristics as "social infrastructure" which includes characteristics such as institutions and government policies. Additionally, Alexandrakis and Livanis (2013) studied economic freedom and performance in Latin America through panel data to compare the results to OECD countries. They used five policy areas of economic freedom to evaluate the impact that output per worker, capital intensity, human capital, and total factor productivity has on economic freedom within a country. The authors concluded that there exists a relationship between a country's level of economic freedom and its economic development that depends on the policy area of economic freedom that is being measured. In addition to the relationship depending on the policy area being measured, it depends on the country the levels are being measured in. In particular, their study found that increasing the size of a government in OECD countries increases output per worker, but for countries in Latin America, increasing the size of their government decreases their output per worker. Along the same lines, Emara and Rebolledo (2019) used panel least estimation to analyze the relationship between economic freedom and some factors of economic performance in Middle East and North Africa (MENA) countries and reached similar conclusions.

The previously mentioned pieces of literature measure the effects of similar components of economic freedom on economic performance, but there are some studies that analyze the impact of different components of economic freedom on economic performance. For example, Heckelman (2000) criticizes the use of aggregate indices of economic freedom to determine if there is a relationship between economic freedom and economic performance. He argues that it is necessary to assess the relationship between the individual components of economic freedom and economic performance because not all components are positively correlated with economic performance which is what most existing literature assume. Additionally, because each component can have different weights in relation to economic growth based on the country as aforementioned literature has revealed. Likewise, Cebula (2011) used panel least square and panel two-stage least square estimates to study the extent at which the 10 components of economic freedom defined by the Heritage Foundation and index of political stability created by the World Bank affect the economic growth of OECD countries. He found that there is a positive 
impact of several components of economic freedom on the logarithm of per capita real GDP of OECD countries. The components he found to have positive impact were business, monetary, labor, investment, fiscal, and property rights freedoms respectively as well as freedom from corruption. He also concluded that there is a positive impact of the World Bank's measure of political stability on the economic growth of OECD countries. Cebula furthered his analysis of this relationship in 2012 by assessing the association between economic freedom and income which the authors measure in terms of per capita real GDP in OECD countries between 2002 and 2006. Their results are in line of those found by Cebula (2011). In the same fashion, Corbi (2007) aimed to strengthen the understanding of the relationship between the determinants of economic freedom and economic growth. Corbi used the economic freedom index developed by the Fraser Institute as well as a sample of 114 countries from 1970 to 2000 . They found that adopting and maintaining institutions that implement policies and infrastructure that increase economic freedom are important to maintain economic growth and prosperity. The findings exhibit a positive relationship between some sub-components of economic freedom related to size of the government (government consumption, transfers and subsidies, government investments), legal structure and property rights (judicial independence, protection of intellectual property, absence of military intervention), sound of money (relationship between the growth of money supply and growth of real GDP, stability of inflation), and freedom to trade internationally (low trade barriers, relationship between the official exchange rate and the black-market rate, and low regulation in the business markets), and economic growth.

Other papers have studied the causal association between economic freedom and economic growth by performing a Granger causality test. For instance, Heckelman (2000) aimed to determine if economic growth is caused by economic freedom, or if economic freedom is caused by economic growth, or if they are jointly determined. His findings indicate that economic freedom causes economic growth, with exception of government intervention for which the causal relationship is in the opposite direction.

Regarding the relationship between governance and economic growth, many studies have confirmed the positive link of improved quality of governance on economic growth. For instance, the study by Emara and Chiu (2016) ${ }^{[1]}$ shows that the per capita 
GDP would rise by about 2 percent if a composite index of governance increases by one unit. Within the same lines, study of Knack and Keefer (1997), Campos and Nugent (1999), Kaufmann, et al. (1999a and 1999b), Knack and Keefer (1995) Mauro (1995), Akcay (2006), Brito-Bigott, Faria, Rodriguez, and Sanchez (2008) Emara and Jhonsa (2014), Emara and Moheildin (2020), and Emara and Al Said (2020) reach the similar conclusions about the importance of governance to economic growth and development. Additionally, Lajili and Philippe (2020) find that political instability has a direct statistically significant negative impact on economic growth. Similar findings are reached in the work of Li, Lu, and Wang (2016), Bjørnskov (2008), and D'Agostino, Dunne, and Pieroni (2016) which all discuss how different aspects of governance impact economic growth within a country.

Against the above background it can be noticed that the literature on the link between economic freedom and governance is very thin. Most research focuses on the impact of each one separately on economic performance and not on whether governance is a pre-condition for economic freedom. The study by Moral and Gan (2018) performed an panel probit analysis over the period 1996 to 2011 on three groups of countries classified by development levels and found that economic freedom is an important factor affecting economic development and that governance is essential at only intermediate stages of development.

Along the same line, using annual data over the period 1990 - 2004 for a group of 133 countries, Altman (2008) finds that economic freedom has a statistical significant impact on economic growth up to a certain threshold level. The study also finds that corporate governance, in addition to economic freedom, is of a considerable importance. A one final study by Ekstrom (2009) uses panel least square methodology for a sample of OECD countries from 2004 through 2007 to estimate the impact of different dimensions of governance and economic freedom on economic growth. The study finds that measures of economic freedom higher levels of trade freedom, business freedom, monetary freedom, and a more secure system of property rights protection have a positive statistically significant impact on economic growth. Additionally, the study finds that economic growth is also positively affected by measures of governance including control of corruption and political stability 


\section{Data}

We use a panel dataset of 14 APAC and 18 OECD countries over the period 1980 - 2017. APAC countries are grouped according to the definition of the $\mathrm{IMF}^{2}$ and the Daniel K. Inouye Asia-Pacific Center for Security Studies ${ }^{3}$. The list of the OECD and APAC countries included in our sample are available in Tables A1 and A2 of the appendix, respectively. ${ }^{4}$

Following Alexandrakis and Livanis (2013), Emara (2014, 2016), and Emara and Rebolledo (2019) and given data availability, our dataset is split into nine sub-periods of different length. As shown on Table A3 of the appendix, between 1980 and 1999 we split out sample into four sub periods of five years; three sub periods of four years between 2000 and 2011, and two sub-periods of three years between 2012 and 2017. Our macroeconomic dataset is extracted from Penn World Table developed by The Center for International Data at the University of California Davis, which is available for the 19502017 period at an annual basis. ${ }^{5}$

The output per worker and capital intensity are computed as the ratio between a country's GDP and the total people engaged in the labor force and a country's stock of physical capital and its GDP, respectively. Both of these variables are measured at chained PPPs (in mil. 2011US\$). Human capital corresponds to an index already calculated in the information available at the Penn World Table's website as well as the TFP.

Next, we use the Fraser Institute ${ }^{6}$ economic freedom dataset, which is available every five years from 1970 to 1999 and annually from 2000 to 2017 . We use the chainlinked overall index of economic freedom as well as five sub-indices covering the following policy areas: size of the government, legal system and property rights, sound of money, economic freedom to trade internationally, and regulation, as detailed in Table 1. Table 2 provides descriptive statistic for the macroeconomic and the freedom variables.

\footnotetext{
${ }^{2}$ Available at https://www.imf.org/external/oap/about.htm

${ }^{3}$ This study also includes Canada, Chile, Cook Islands, French Polynesia, Nauru, New Caledonia, Niue, Pakistan, Peru, and Russia as part of the APAC region. Available at http://apcss.org/about-2/ap-countries/

${ }^{4}$ Although countries such as Australia, Canada, Chile, and United States are part of the OECD we have included only as part of the APAC region.

${ }^{5}$ Available at http://cid.econ.ucdavis.edu/pwt.html

${ }^{6}$ Available at https://www.fraserinstitute.org/economic-freedom/
} 
Table 1: Economic Freedom Index and its components

\begin{tabular}{|c|c|}
\hline Index by Policy Area & Individual Components \\
\hline $\mathbf{E F}_{1}:$ Size of Government & $\begin{array}{l}\text { A. Government consumption } \\
\text { B. Transfers and subsidies } \\
\text { C. Government enterprises and investment } \\
\text { D. Top marginal tax rate: } \\
\text { - Top marginal income tax rate } \\
\text { - Top marginal income and payroll tax rate }\end{array}$ \\
\hline $\mathbf{E F}_{2}$ : Legal System and Property Rights & $\begin{array}{l}\text { A. Judicial Independence } \\
\text { B. Impartial courts } \\
\text { C. Protection of property rights } \\
\text { D. Military interference in rule of law and politics } \\
\text { E. Integrity of the legal system } \\
\text { F. Legal enforcement of contracts } \\
\text { G. Regulatory costs of the sale of real property } \\
\text { H. Reliability of police } \\
\text { I. Business costs of crime }\end{array}$ \\
\hline $\mathrm{EF}_{3}$ : Sound of Money & $\begin{array}{l}\text { A. Money growth } \\
\text { B. Standard deviation of inflation } \\
\text { C. Inflation: most recent year } \\
\text { D. Freedom to own foreign currency bank accounts }\end{array}$ \\
\hline $\mathbf{E F}_{4}:$ Freedom to Trade Internationally & $\begin{array}{l}\text { A. Tariffs: } \\
\text { - Revenue from trade taxes ( } \% \text { of trade sector) } \\
\text { - Mean tariff rate } \\
\text { B. Regulatory trade barriers: } \\
\text { - Non-tariff trade barriers } \\
\text { - Compliance costs of importing and exporting } \\
\text { C. Black-market exchange rates } \\
\text { D. Controls of the movement of capital and people: } \\
\text { Foreign ownership/investment restrictions } \\
\text { - Capital controls } \\
\text { - Freedom of foreigners to visit }\end{array}$ \\
\hline $\mathrm{EF}_{5}$ : Regulation & $\begin{array}{l}\text { A. Credit market regulations: } \\
\text { - } \quad \text { Ownership of banks } \\
\text { - } \quad \text { Private sector credit } \\
\text { B. Labor market regulations: } \\
\text { - Hiring regulations and minimum wage } \\
\text { - Hiring and firing regulations } \\
\text { - } \quad \text { Centralized collective bargaining } \\
\text { - Hours regulations } \\
\text { - } \quad \text { Conscription } \\
\text { C. Business regulations: } \\
\text { - } \quad \text { Administrative requirements } \\
\text { - } \quad \text { Bureaucracy costs } \\
\text { - } \quad \text { Extra payments/bribes/favoritism a business } \\
\text { - Licensing restrictions } \\
\text { - Cost of a tax compliance } \\
\end{array}$ \\
\hline
\end{tabular}

Source: Fraser Institute (https://www.fraserinstitute.org/economic-freedom/approach). 
Table 2: Descriptive Statistics

\begin{tabular}{|c|c|c|c|c|c|}
\hline APAC Countries & & & & & \\
\hline Variable & Observations & Mean & Std. Dev. & Min. & Max. \\
\hline $\ln y$ & 126 & 10.265 & 0.926 & 7.866 & 11.647 \\
\hline$[\alpha /(1-\alpha)] \ln k$ & 126 & 0.544 & 0.160 & 0.1404 & 0.910 \\
\hline $\ln h$ & 126 & 0.994 & 0.239 & 0.279 & 1.338 \\
\hline $\ln A$ & 126 & -0.475 & 0.329 & -1.30 & 0 \\
\hline Economic Freedom (EF) & 126 & 7.086 & 1.239 & 2.41 & 8.83 \\
\hline $\mathrm{EF}_{1}$ : Size of Government & 126 & 6.726 & 1.012 & 4.08 & 8.63 \\
\hline $\mathrm{EF}_{2}:$ Legal System & 126 & 6.201 & 1.911 & 2.19 & 9.17 \\
\hline $\mathrm{EF}_{3}:$ Sound of Money & 126 & 8.146 & 1.848 & 0 & 9.84 \\
\hline $\mathrm{EF}_{4}$ : Freedom to Trade Internationally & 126 & 7.165 & 1.689 & 1.3 & 9.96 \\
\hline $\mathrm{EF}_{5}$ : Regulation & 126 & 7.195 & 1.256 & 3.39 & 9.11 \\
\hline \multicolumn{6}{|l|}{ OECD Countries } \\
\hline Variable & Observations & Mean & Std. Dev. & Min. & Max. \\
\hline $\ln y$ & 162 & 11.074 & 0.334 & 10.118 & 12.021 \\
\hline$[\alpha /(1-\alpha)] \ln k$ & 162 & 0.685 & 0.138 & 0.3608 & 1.102 \\
\hline $\ln h$ & 162 & 1.080 & 0.170 & 0.443 & 1.322 \\
\hline $\ln A$ & 162 & -0.094 & 0.158 & -0.635 & 0.291 \\
\hline Economic Freedom (EF) & 162 & 7.308 & 0.855 & 3.64 & 8.79 \\
\hline $\mathrm{EF}_{1}$ : Size of Government & 162 & 5.367 & 1.120 & 2.7 & 8.09 \\
\hline $\mathrm{EF}_{2}:$ Legal System & 162 & 7.553 & 1.145 & 3.98 & 9.28 \\
\hline $\mathrm{EF}_{3}:$ Sound of Money & 162 & 8.642 & 1.742 & 0.78 & 9.84 \\
\hline $\mathrm{EF}_{4}$ : Freedom to Trade Internationally & 162 & 8.144 & 1.031 & 3.43 & 9.76 \\
\hline $\mathrm{EF}_{5}$ : Regulation & 162 & 6.834 & 1.121 & 3.87 & 8.74 \\
\hline
\end{tabular}

For governance indicators, we use selected indicators from the Worldwide Governance Indicators, which is published annually since 1998 and compiled by Kaufmann, Kraay, and Zoido-Lobatón (1999) and Kaufmann, Kraay, and Mastruzzi (2005). These indicators are based on some 30 opinion and perception-based surveys of various governance measures from investment consulting firms, non-government organizations, think tanks, governments, and multilateral agencies; and classified into six areas including government effectiveness, political stability, control of corruption and regulatory quality, voice and accountability, and rule of law. Our analysis will only focus on four of these six governance areas. Table A4 of the appendix presents a description of the components of the governance index. 


\section{Methodology}

In order to estimate the relationship between output per worker and economic freedom, we follow the methodological approaches developed by Hall and Jones (1999) and used in Alexandrakis and Livanis (2013) and Emara and Rebolledo (2019). In these papers, the authors use a traditional Cobb-Douglas production function representing a country's aggregate output, and decompose it to express the output per worker as a function of three main components: the stock of physical capital, human capital, and total factor productivity (TFP). ${ }^{7}$ Following this approach and using a panel least square estimation methodology, we estimate the impact of a country's level of economic freedom on the output per worker through the following equations:

$$
\begin{aligned}
& \ln y_{i, t}=\beta_{0}+\sum_{j=1}^{5} \beta_{j} E F_{i, j, t-s}+\sum_{j=1}^{5} \alpha_{j} \cdot A P A C_{i} \cdot E F_{i, j, t-s}+\delta_{i}+\gamma_{t}+\mu_{i, t} \\
& \left(\frac{\alpha}{1-\alpha}\right) \ln k_{i, t}=\beta_{0}+\sum_{j=1}^{5} \beta_{j} E F_{i, j, t-s}+\sum_{j=1}^{5} \alpha_{j} \cdot A P A C_{i} \cdot E F_{i, j, t-s}+\delta_{i}+\gamma_{t}+\mu_{i, t} \\
& \operatorname{lnh} c_{i, t}=\beta_{0}+\sum_{j=1}^{5} \beta_{j} E F_{i, j, t-s}+\sum_{j=1}^{5} \alpha_{j} \cdot A P A C_{i} \cdot E F_{i, j, t-s}+\delta_{i}+\gamma_{t}+\mu_{i, t} \\
& \ln A_{i, t}=\beta_{0}+\sum_{j=1}^{5} \beta_{j} E F_{i, j, t-s}+\sum_{j=1}^{5} \alpha_{j} \cdot A P A C_{i} \cdot E F_{i, j, t-s}+\delta_{i}+\gamma_{t}+\mu_{i, t}
\end{aligned}
$$

Where $y_{i, t}, k_{i, t}, h c_{i, t}$, and $A_{i, t}$ correspond to the output per worker, capital intensity, human capital, and TFP of the country $i$ at the time $t$, respectively. In addition, $E F_{i, j, t-s}$ corresponds to a lagged measure of country $i$ 's economic freedom in the policy area $j$ at time $t-s$ (where $s$ corresponds to the lag). Also, $A P A C_{i}$ represents a dummy variable that takes the value 1 for APAC countries, and zero for OECD countries. By including the interaction between this variable and our measure for each country's economic freedom, we will be able to capture the difference of the impact of economic freedom between OECD and APAC countries. Specifically, given the regression specifications presented in equations (1) to (4), the total effect of economic freedom in the policy area $j$ for OECD countries will be given by $\beta_{j}$, while for APAC countries is estimated by adding the coefficient $\beta_{j}$ to the coefficient $\alpha_{j}$ and the statistical significance of the effect is estimated

\footnotetext{
${ }^{7}$ This methodology assumes that the capital intensity, human capital, and TFP are proxies for a country's total output and therefore, can be used as alternative measures to assess the impact of a country's economic freedom on its output per worker (Alexandrakis and Livanis, 2013; Emara and Rebolledo 2019).
} 
using the standard errors of these two coefficients. According to the literature, since most of the reforms conducted in these areas have long-term effects where the impact can be observed after a certain time $\operatorname{lag}^{8}$, we use the economic freedom index at the beginning of each sub period following Alexandrakis and Livanis (2013) Emara and Rebolledo (2019). Furthermore, as per the study of Caudill, S., Zanella, F., and Mixon, F. (2000) since the economic freedom index computed by the Fraser institute is proved not to be one dimensional and covering 24 orthogonal items including government spending, taxes, inflation, trade, exchange rate, infrastructure, and others (as noted in Table 1), hence adding multiple sub-indices in one regression will not lead to multicollinearity problems.

For panel fixed effect methodology, we include country and time fixed-effects to control for all factors that vary among countries but are constant over time $\left(\delta_{i}\right)$, and timespecific events affecting all countries $\left(\gamma_{t}\right)$, respectively. Finally, $\mu_{i, t}$ represents the error term associated with the country $i$ at time $t$. As in Alexandrakis and Livanis (2013) and Emara and Rebolledo (2019), we use the averaged value for each one of these variables by sub-period as dependent variables presented in equations (1) to (4).

Next to explore the role of governance on the relationship between economic freedom and output per worker, following Emara and Chiu (2016), we use the principal component analysis to create an index for governance that consists of four indicators including government effectiveness, political stability, control of corruption, and voice and accountability. Similar to our discussion of the economic freedom indicators, since governance has a long-term effect, the beginning of each period governance index is

interacted with the $E F_{i, j, t-s}$ index in each of the above four equations and the total effect of economic freedom in the presence of good institutions is computed in the same manner as previously explained.

\section{Estimation Results}

In this section, we report the impact of the various economic freedom measures on economic performance and analyze how this impact might be different if we split the

\footnotetext{
${ }^{8}$ Romer and Romer (2004) and Gwartney, J., Holcombe, R., and Lawson, R. (2004).
} 
sample between OECD and APAC countries. In addition, we interact the governance indicator with economic freedom measures, to access the impact of governance quality on the effectiveness of economic freedom measures in improving economic performance as highlighted in several studies, including Knack and Keefer (1997), Campos and Nugent (1999), Kaufmann, et al. (1999a and 1999b), Knack and Keefer (1995) Mauro (1995), who found that the improvement in institutional quality boosts economic growth.

As a first pass on the relationship between economic freedom and economic performance, we analyze the correlations and their statistical significance between the economic freedom index, its five sub-indices, output per worker, and its three alternative measures, as presented on Table 3.

Table 3: Correlation Matrix

\begin{tabular}{|c|c|c|c|c|c|c|c|c|c|c|}
\hline \multicolumn{11}{|c|}{ APAC Countries } \\
\hline & $\ln y$ & {$[\alpha /(1-\alpha)] \ln k$} & $\ln h$ & $\ln A$ & $\mathrm{EF}$ & $\mathrm{EF}_{1}: \mathrm{SG}$ & $\mathrm{EF}_{2}: \mathrm{LS}$ & $\mathrm{EF}_{3}: \mathrm{SM}$ & $\mathrm{EF}_{4}: \mathrm{FT}$ & $\mathrm{EF}_{5}: \mathrm{RE}$ \\
\hline $\ln y$ & 1 & & & & & & & & & \\
\hline$[\alpha(1-\alpha)] \ln k$ & $0.542 *$ & 1 & & & & & & & & \\
\hline $\ln h$ & $0.887^{*}$ & $0.539^{*}$ & 1 & & & & & & & \\
\hline $\ln A$ & $0.869^{*}$ & 0.122 & $0.782 *$ & 1 & & & & & & \\
\hline $\mathrm{EF}$ & $0.810^{*}$ & $0.584 *$ & $0.712 *$ & $0.608^{*}$ & 1 & & & & & \\
\hline $\mathrm{EF}_{1}: \mathrm{SG}$ & 0.050 & $0.363^{*}$ & 0.109 & -0.139 & $0.352^{*}$ & 1 & & & & \\
\hline $\mathrm{EF}_{2}: \mathrm{LS}$ & $0.815^{*}$ & $0.416^{*}$ & $0.657^{*}$ & $0.715^{*}$ & $0.828^{*}$ & -0.073 & 1 & & & \\
\hline $\mathrm{EF}_{3}: \mathrm{SM}$ & $0.598^{*}$ & $0.488^{*}$ & $0.534 *$ & $0.422 *$ & $0.869 *$ & $0.276^{*}$ & $0.608^{*}$ & 1 & & \\
\hline $\mathrm{EF}_{4}: \mathrm{FT}$ & $0.765^{*}$ & $0.490 *$ & $0.650^{*}$ & $0.599 *$ & $0.906^{*}$ & $0.314 *$ & $0.720 *$ & $0.697 *$ & 1 & \\
\hline $\mathrm{EF}_{5}: \mathrm{RE}$ & $0.806^{*}$ & $0.578^{*}$ & $0.766^{*}$ & $0.600 *$ & $0.894 *$ & $0.213 *$ & $0.759^{*}$ & $0.731 *$ & $0.752 *$ & 1 \\
\hline \multicolumn{11}{|c|}{ OECD Countries } \\
\hline & $\ln y$ & {$[\alpha(1-\alpha)] \ln k$} & $\ln h$ & $\ln A$ & $\mathrm{EF}$ & $\mathrm{EF}_{1}: \mathrm{SG}$ & $\mathrm{EF}_{2}: \mathrm{LS}$ & $\mathrm{EF}_{3}: \mathrm{SM}$ & $\mathrm{EF}_{4}: \mathrm{FT}$ & $\mathrm{EF}_{5}: \mathrm{RE}$ \\
\hline $\begin{array}{l}\ln y \\
{[\alpha /(1-\alpha)] \ln }\end{array}$ & 1 & & & & & & & & & \\
\hline$k$ & $0.251^{*}$ & 1 & & & & & & & & \\
\hline $\ln h$ & $0.687^{*}$ & $0.203 *$ & 1 & & & & & & & \\
\hline $\ln A$ & $0.349^{*}$ & $-0.629 *$ & 0.029 & 1 & & & & & & \\
\hline EF & $0.689 *$ & 0.142 & $0.7508^{*}$ & 0.140 & 1 & & & & & \\
\hline $\mathrm{EF}_{1}: \mathrm{SG}$ & $0.274 *$ & 0.025 & 0.044 & 0.091 & $0.353^{*}$ & 1 & & & & \\
\hline $\mathrm{EF}_{2}: \mathrm{LS}$ & $0.393^{*}$ & -0.057 & $0.656^{*}$ & $0.163^{*}$ & $0.651^{*}$ & -0.141 & 1 & & & \\
\hline $\mathrm{EF}_{3}: \mathrm{SM}$ & $0.611^{*}$ & $0.346^{*}$ & $0.666^{*}$ & -0.037 & $0.864^{*}$ & 0.12 & $0.466^{*}$ & 1 & & \\
\hline $\mathrm{EF}_{4}: \mathrm{FT}$ & $0.3163^{*}$ & -0.0592 & $0.5028^{*}$ & 0.1208 & $0.7512 *$ & 0.0533 & $0.446^{*}$ & $0.679 *$ & 1 & \\
\hline $\mathrm{EF}_{5}: \mathrm{RE}$ & $0.713^{*}$ & 0.091 & $0.655^{*}$ & $0.223^{*}$ & $0.765^{*}$ & $0.263 *$ & $0.470 *$ & $0.529 *$ & $0.384^{*}$ & 1 \\
\hline
\end{tabular}


As we can observe, there is a positive and statistically significant relationship between the aggregate index of economic freedom and output per worker and human capital, for both APAC and OECD countries. Surprisingly, the correlation between economic freedom with capital intensity and total factor productivity is only statistically significant for APAC countries. Looking at the correlation between economic freedom by policy area and output per worker in APAC countries, we find that it is positive and statistically significant for almost all policy areas with exception of the size of government for which the correlation is insignificant. We obtain similar results when we study the correlation between economic freedom by policy areas and capital intensity and total factor productivity. In addition, we observe that all the correlation between economic freedom by policy areas and human capital positive and statistically significant, as expected, with the exception of the size of government sub-index.

Similarly, for OECD countries the correlation between economic freedom by policy area and output per worker is positive and statistically significant. When we look at the correlation between the economic freedom by policy area and the components of output per worker, we find that for almost all policy areas is positive and statistically significant for human capital and for only two areas for the total factor productivity. Interestingly, only the correlation between economic freedom in the sound of money policy area and capital intensity results positive and statistically significant.

To estimate the impact of economic freedom on economic growth we begin by highlighting our baseline regressions for the full sample. Table 4 presents results of the effect of economic freedom on output per worker, capital intensity, human capital and total factor productivity. It is important to note that for all regressions, as reported on the tables, multiple statistical tests are performed including, the variance inflation factor $(\mathrm{VIF})^{9}$ to confirm the non-existence of multicollinearity, the Hausman test to confirm that fixed effects methodology is the best fit for our models, the Friedman test to confirm the absence of cross-sectional dependence, and the F-test to confirm the joint significance of the time period dummies.

\footnotetext{
${ }^{9}$ The VIF's for all models are below 10 .
} 
Table 4: The Effect of (Aggregate) Economic Freedom on Output per worker, Capital Intensity, Human Capital, and Total Factor Productivity

\begin{tabular}{|c|c|c|c|c|}
\hline & $\begin{array}{r}\ln y \\
(1)\end{array}$ & $\begin{array}{c}{[\alpha /(1-\alpha)] \ln k} \\
(2)\end{array}$ & $\begin{array}{l}\ln h \\
(3)\end{array}$ & $\begin{array}{l}\ln A \\
(4)\end{array}$ \\
\hline Economic Freedom & $\begin{array}{c}0.0583 * * * \\
(-0.0177)\end{array}$ & $\begin{array}{c}0.0314 * * * \\
(-0.010)\end{array}$ & $\begin{array}{c}0.0208 * * * \\
(-0.0068)\end{array}$ & $\begin{array}{c}0.0087 \\
(-0.0138)\end{array}$ \\
\hline Sub-period 1985-1989 & $\begin{array}{c}0.0487 \\
(-0.0339)\end{array}$ & $\begin{array}{c}-0.004 \\
(-0.0212)\end{array}$ & $\begin{array}{c}0.0490 * * * \\
(-0.013)\end{array}$ & $\begin{array}{c}-0.0615^{* *} \\
(-0.0264)\end{array}$ \\
\hline Sub-period 1990-1994 & $\begin{array}{c}0.1546 * * * \\
(-0.0364)\end{array}$ & $\begin{array}{c}0.0046 \\
(0.0225)\end{array}$ & $\begin{array}{c}0.0820 * * * \\
(-0.014)\end{array}$ & $\begin{array}{c}-0.0754 * * * \\
(-0.0283)\end{array}$ \\
\hline Sub-period 1995-1999 & $\begin{array}{c}0.2808 * * * \\
(-0.0407)\end{array}$ & $\begin{array}{c}0.002 \\
(-0.0247)\end{array}$ & $\begin{array}{c}0.1129 * * * \\
(-0.0156)\end{array}$ & $\begin{array}{c}-0.0491 \\
(-0.0316)\end{array}$ \\
\hline Sub-period 2000-2003 & $\begin{array}{c}0.3486 * * * \\
(-0.0431)\end{array}$ & $\begin{array}{l}-0.0071 \\
(-0.0260)\end{array}$ & $\begin{array}{c}0.1404 * * * \\
(-0.0165)\end{array}$ & $\begin{array}{l}-0.0157 \\
(-0.0335)\end{array}$ \\
\hline Sub-period 2004-2007 & $\begin{array}{c}0.4867 * * * \\
(-0.0427)\end{array}$ & $\begin{array}{l}0.0517 * * \\
(-0.0268)\end{array}$ & $\begin{array}{c}0.1631 * * * \\
(-0.0163)\end{array}$ & $\begin{array}{c}0.0009 \\
(-0.0331)\end{array}$ \\
\hline Sub-period 2008-2011 & $\begin{array}{c}0.6036^{* * * *} \\
(-0.0417)\end{array}$ & $\begin{array}{c}0.1344 * * * \\
(-0.025)\end{array}$ & $\begin{array}{c}0.1885^{* * * *} \\
(-0.016)\end{array}$ & $\begin{array}{l}-0.0299 \\
(-0.0324)\end{array}$ \\
\hline Sub-period 2012-2014 & $\begin{array}{c}0.6876^{* * * *} \\
(-0.0417)\end{array}$ & $\begin{array}{l}0.1819 * * * \\
(-0.02527)\end{array}$ & $\begin{array}{c}0.2083 * * * \\
(-0.016)\end{array}$ & $\begin{array}{c}-0.052 \\
(-0.0324)\end{array}$ \\
\hline Sub-period 2015-2017 & $\begin{array}{c}0.7147 * * * \\
(-0.0426)\end{array}$ & $\begin{array}{l}0.2170 * * * \\
(0.0257)\end{array}$ & $\begin{array}{c}0.2240 * * * \\
(-0.0163)\end{array}$ & $\begin{array}{c}-0.0491 \\
(-0.0331)\end{array}$ \\
\hline Constant & $\begin{array}{c}9.9309 * * * \\
(-0.1119)\end{array}$ & $\begin{array}{c}0.3311 * * * \\
(-0.0663)\end{array}$ & $\begin{array}{c}0.7622 * * * \\
(-0.0429)\end{array}$ & $\begin{array}{c}-0.2867 * * * \\
(-0.0869) \\
\end{array}$ \\
\hline Within- ${ }^{2}$ & 0.837 & 0.5944 & 0.7467 & 0.0698 \\
\hline $\begin{array}{l}\text { \# Observations } \\
\text { \# Countries }\end{array}$ & $\begin{array}{c}288 \\
32\end{array}$ & $\begin{array}{c}288 \\
32\end{array}$ & $\begin{array}{c}288 \\
32\end{array}$ & $\begin{array}{c}288 \\
32\end{array}$ \\
\hline $\begin{array}{l}\text { Period dummies } \mathrm{F}(8,247) \\
\text { p-value }\end{array}$ & 0.0000 & 0.0000 & 0.0000 & 0.0331 \\
\hline $\begin{array}{l}\text { Friedman's Cross- } \\
\text { Sectional Independence }\end{array}$ & 13.725 & 7.033 & 16.625 & 2.871 \\
\hline Hausman Test p-value & 0.0000 & 0.4669 & 0.0000 & 0.0002 \\
\hline
\end{tabular}

Notes: $* * * 1 \%, * * 5 \%, * 10 \%$. Standard errors in parentheses. Random effects model is used in Column (2).

The results of Column (1) confirm that economic freedom has a positive and a statistically significant impact on output per worker for the full sample and after controlling for country and period fixed effects. The results indicate that a ten percent increase in the economic freedom index results in an increase in output per worker by about $0.58 \%$ for the full sample. This result is consistent with (Barro, 1997; De Haan and Siermann, 1998; De Haan and Sturm, 2000; Heckelman and Stroup, 2000). The regressions of Columns (2) to (4) are used to explore the channel through which economic freedom positively affects output per worker. As the three columns confirm, a ten percent increase in economic freedom has a positive impact on output per worker by improving capital intensity and human capital accumulation by about $0.31 \%$ and $0.21 \%$, respectively. Surprisingly, the results confirm that effect of economic freedom on total 
factor productivity is statistically insignificant but in line with the results of Emara and Rebolledo (2019).

Next, to differentiate between the OECD and the APAC samples, a dummy for the APAC region and its interaction term of the economic freedom variable are added to the model, as shown in Table 5. Column (1) indicates that the relationship between output per worker and the aggregated index for economic freedom is positive and statistically significant where a ten percent increase in the index leads to an increase in output per worker by about $0.53 \%$ for OECD countries. Results in columns (2) to (4) suggest the main channel that explains this relationship is through total factor productivity. In particular, our results indicate that for OECD countries the improvement in output per worker induced by economic freedom is mainly explained by total factor productivity where a ten percent increase in the economic freedom index leads to $0.27 \%$ increase in total factor productivity. It is interesting to note that the channels of capital intensity and human capital are statistically insignificant. This result is in line with the full sample results of Alexandrakis and Livanis (2013) Emara and Rebolledo (2019).

In contrast, for APAC countries our results of Table 6 show the computation of the total effects of economic freedom. Specifically, it shows the total effect of each one of the components of the economic freedom in the policy area $\mathrm{j}$ (i.e., $E F_{j}$ ) and its interaction with the regional dummy for APAC countries (i.e., $E F_{j} \times A P A C=1$ ) and the computation of the statistical significance of these coefficients, as explained in the previous section.

The results of the table indicate that the impact of the aggregated index for economic freedom is positive and statistically significant where a ten percent increase in the index leads to an increase of about $0.6 \%$ in on output per worker. In addition, the effect of a ten percent increase in the economic freedom index leads to an increase in capital intensity and human capital by about $0.46 \%$ and $0.27 \%$, respectively. Additionally, our results imply that total factor productivity is not an important channel through which economic freedom affects output per worker in the APAC region. 
Table 5: The Effect of (Aggregate) Economic Freedom on Output per worker, Capital Intensity, Human Capital, and Total Factor Productivity for APAC countries relative to OECD countries

\begin{tabular}{|c|c|c|c|c|}
\hline & $\begin{array}{l}\ln y \\
(1)\end{array}$ & $\begin{array}{c}{[\alpha /(1-\alpha)] \ln k} \\
(2)\end{array}$ & $\begin{array}{l}\ln h \\
(3)\end{array}$ & $\begin{array}{c}\ln A \\
(4)\end{array}$ \\
\hline \multirow[t]{2}{*}{ EF: Economic Freedom } & $0.0528 * *$ & -0.0171 & 0.0057 & $0.0269^{*}$ \\
\hline & $(-0.0245)$ & $(-0.0147)$ & $(-0.0093)$ & $(-0.019)$ \\
\hline \multirow[t]{2}{*}{ Economic Freedom $\times$ APAC } & 0.0076 & $0.0628 * * *$ & $0.0211 * *$ & $-0.0254 *$ \\
\hline & $(-0.0234)$ & $(-0.0141)$ & $(-0.0089)$ & $(-0.0181)$ \\
\hline \multirow[t]{2}{*}{ Sub-period 1985-1989 } & 0.0494 & 0.0022 & $0.0510 * * *$ & $-0.0640 * *$ \\
\hline & $(-0.0341)$ & $(-0.0205)$ & $(-0.0129)$ & $(-0.0264)$ \\
\hline \multirow[t]{2}{*}{ Sub-period 1990-1994 } & $0.1565 * * *$ & 0.0229 & $0.0873 * * *$ & $-0.0817 * * *$ \\
\hline & $(-0.037)$ & $(-0.0222)$ & $(-0.014)$ & $(-0.0286)$ \\
\hline \multirow[t]{2}{*}{ Sub-period 1995-1999 } & $0.2835 * * *$ & 0.0365 & $0.1203 * * *$ & $-0.0580 *$ \\
\hline & $(-0.0416)$ & $(-0.025)$ & $(-0.0158)$ & $(-0.0322)$ \\
\hline \multirow[t]{2}{*}{ Sub-period 2000-2003 } & $0.3522 * * *$ & 0.0275 & $0.1504 * * *$ & -0.0276 \\
\hline & $(-0.0445)$ & $(-0.0268)$ & $(-0.0169)$ & $(-0.0345)$ \\
\hline \multirow[t]{2}{*}{ Sub-period 2004-2007 } & $0.4901 * * *$ & $0.0850 * * *$ & $0.1727 * * *$ & -0.0106 \\
\hline & $(-0.044)$ & $(-0.0265)$ & $(-0.0167)$ & $(-0.0341)$ \\
\hline \multirow[t]{2}{*}{ Sub-period 2008-2011 } & $0.6065 * * *$ & $0.1627 * * *$ & $0.1964 * * *$ & -0.0395 \\
\hline & $(-0.0427)$ & $(-0.0256)$ & $(-0.0162)$ & $(-0.033)$ \\
\hline \multirow[t]{2}{*}{ Sub-period 2012-2014 } & $0.6903 * * *$ & $0.2094 * * *$ & $0.2160 * * *$ & $-0.0612 *$ \\
\hline & $(-0.0427)$ & $(-0.0257)$ & $(-0.0162)$ & $(-0.033)$ \\
\hline \multirow[t]{2}{*}{ Sub-period 2015-2017 } & $0.7174 * * *$ & $0.2448 * * *$ & $0.2317 * * *$ & $-0.0584^{*}$ \\
\hline & $(-0.0436)$ & $(-0.0262)$ & $(-0.0165)$ & $(-0.0337)$ \\
\hline \multirow[t]{2}{*}{ Constant } & $9.9444 * * *$ & $0.4636^{* * *}$ & $0.7997 * * *$ & $-0.3320 * * *$ \\
\hline & $(-0.1196)$ & $(-0.0719)$ & $(-0.0453)$ & $(-0.0926)$ \\
\hline Within- $\mathrm{R}^{2}$ & 0.837 & 0.6248 & 0.7524 & 0.0771 \\
\hline \# Observations & 288 & 288 & 288 & 288 \\
\hline \# Countries & 32 & 32 & 32 & 32 \\
\hline \multicolumn{5}{|l|}{ Period dummies $\mathrm{F}(8,246)$} \\
\hline p-value & 0.0000 & 0.0000 & 0.0000 & 0.0340 \\
\hline \multicolumn{5}{|l|}{ Friedman's Cross Sectional } \\
\hline Independence & 13.167 & 4.233 & 14.150 & 2.717 \\
\hline Hausman Test p-value & 0.0000 & 0.0000 & 0.0000 & 0.0002 \\
\hline
\end{tabular}

Notes: $* * * 1 \%, * * 5 \%, * 10 \%$. Standard errors in parentheses.

Table 6: Total Effect of Economic Freedom on the output per worker, capital intensity, human capital, and total factor productivity in APAC countries

\begin{tabular}{ccccc}
\hline & $\begin{array}{c}\ln y \\
(1)\end{array}$ & $\begin{array}{c}{[\alpha /(1-\alpha)] \ln k} \\
(2)\end{array}$ & $\begin{array}{c}\ln h \\
(3)\end{array}$ & $\begin{array}{c}\ln A \\
(4)\end{array}$ \\
\hline EF: Economic Freedom in APAC & $.060 * * *$ & $.046 * * *$ & $0.027 * * *$ & 0.0015 \\
& $(0.019)$ & $(0.011)$ & $(0.007)$ & $(.0147)$ \\
\hline \hline
\end{tabular}

Notes: $* * * 1 \%, * * 5 \%, * 10 \%$. In parentheses we present the standard error to the total effect of adding up the coefficient of $\mathrm{EF}$ to the interaction between this coefficient and a regional dummy variable that takes the value 1 for APAC countries (i.e., EF $\times$ APAC). (The coefficients are taken from the results of the previous table)

To further analyze the impact of economic freedom, Table 7 shows a detailed estimation of the impact of each policy area on output per worker and its three components, capital intensity, human capital, and total factor productivity. As the results show, for OECD countries, there is a positive and statistically significant association 
between size of the government and economic performance where a ten percent increase in this sub-index leads to about $0.41 \%$ increase in output per worker that is mainly explained through an improvement of total factor productivity about $0.35 \%$. Similarly, a ten percent increase in country's legal system index leads to a positive effect on its output per worker by about $0.36 \%$ which works through improving total factor productivity by about $0.43 \%$, lowering capital intensity by about $0.30 \%$, and lowering human capital accumulation by about $0.2 \%$. In a similar way, a ten percent increase in the regulation index leads to a reduction in output per worker by about $0.4 \%$ which is mainly explained by lowering human capital by about $0.17 \%$.

Intuitively our results for the OECD sample imply that a smaller government (represented through a lower public consumption and expenditure), stronger property rights and rule of law (represented through an impartial judiciary system that guarantees the enforcement of legal contracts), and a greater deregulation of credit, labor and business market operations, have a positive (and statistically significant) effect on a country's output per worker. Furthermore, in the OECD region, a tighter monetary policy (represented by lower and more stable inflation) seems to increase both capital intensity and human capital accumulation. Finally, a strong legal system reduces both capital intensity and human capital but enhances the country's total factor productivity.

Similarly, Table 8 shows the impact and the statistical significance of the different components of economic freedom on the output per worker, capital intensity, and total factor productivity for APAC countries. Column (1) indicates that a ten percent increase in the sub-indices of country's size of government and freedom to trade internationally have a positive and statistically significant impact on its output per worker, with an impact of $0.5 \%$ and $0.4 \%$, respectively. On the contrary, a ten percent increase in the country's sound of money sub-index, or a tighter monetary policy, decreases its output per worker of about $0.29 \%$. Our results also imply that a country's legal system and regulations do not have any significant effect on its output per worker. 
Table 7: The Effect of Economic Freedom by policy area on Output per worker, Capital Intensity, Human Capital, and Total Factor Productivity APAC countries relative to OECD countries

\begin{tabular}{|c|c|c|c|c|}
\hline & $\begin{array}{r}\ln y \\
(1) \\
\end{array}$ & $\begin{array}{c}{[\alpha /(1-\alpha)] \ln k} \\
(2)\end{array}$ & $\begin{array}{l}\ln h \\
(3) \\
\end{array}$ & $\begin{array}{c}\ln A \\
(4) \\
\end{array}$ \\
\hline $\mathrm{EF}_{1}$ : Size of Government (SG) & $\begin{array}{l}0.0405 * * \\
(-0.0199)\end{array}$ & $\begin{array}{c}-0.0155 \\
(-0.0124)\end{array}$ & $\begin{array}{c}0.0004 \\
(-0.0073)\end{array}$ & $\begin{array}{l}0.0347 * * \\
(-0.0159)\end{array}$ \\
\hline $\mathrm{EF}_{2}$ : Legal System (LS) & $\begin{array}{c}0.0364^{*} \\
(-0.0209)\end{array}$ & $\begin{array}{c}-0.0304 * * \\
(-0.013)\end{array}$ & $\begin{array}{c}-0.0199 * * * \\
(-0.0076)\end{array}$ & $\begin{array}{l}0.0431 * * \\
(-0.0167)\end{array}$ \\
\hline $\mathrm{EF}_{3}$ : Sound of Money (SM) & $\begin{array}{c}0.0133 \\
(-0.0118)\end{array}$ & $\begin{array}{l}0.0158 * * \\
(-0.0073)\end{array}$ & $\begin{array}{l}0.0107 * * \\
(-0.0043)\end{array}$ & $\begin{array}{c}-0.0087 \\
(-0.0095)\end{array}$ \\
\hline $\mathrm{E}_{4}:$ Freedom to Trade Internationally (FT) & $\begin{array}{c}0.027 \\
(-0.0173)\end{array}$ & $\begin{array}{l}-0.0096 \\
(-0.0107)\end{array}$ & $\begin{array}{c}0.0093 \\
(-0.0063)\end{array}$ & $\begin{array}{c}0.0202 \\
(-0.0138)\end{array}$ \\
\hline $\mathrm{EF}_{5}$ : Regulation (RE) & $\begin{array}{l}-0.0402 * \\
(-0.0207)\end{array}$ & $\begin{array}{c}-0.0166 \\
(-0.0129)\end{array}$ & $\begin{array}{c}-0.0169 * * \\
(-0.0076)\end{array}$ & $\begin{array}{c}-0.0227 \\
(-0.0165)\end{array}$ \\
\hline $\mathrm{EF}_{1}: \mathrm{SG} \times \mathrm{APAC}$ & $\begin{array}{c}0.0297 \\
(-0.0301)\end{array}$ & $\begin{array}{c}0.0222 \\
(-0.0187)\end{array}$ & $\begin{array}{l}-0.0057 \\
(-0.011)\end{array}$ & $\begin{array}{c}-0.0097 \\
(-0.0241)\end{array}$ \\
\hline $\mathrm{EF}_{2}: \mathrm{LS} \times \mathrm{APAC}$ & $\begin{array}{c}-0.0182 \\
(-0.0324)\end{array}$ & $\begin{array}{l}0.0489 * * \\
(-0.0201)\end{array}$ & $\begin{array}{c}0.0161 \\
(-0.0118)\end{array}$ & $\begin{array}{c}-0.0265 \\
(-0.0259)\end{array}$ \\
\hline $\mathrm{EF}_{3}: \mathrm{SM} \times \mathrm{APAC}$ & $\begin{array}{c}-0.0422 * * \\
(-0.0169)\end{array}$ & $\begin{array}{c}-0.0276^{* * *} \\
(-0.0105)\end{array}$ & $\begin{array}{c}-0.0262 * * * \\
(-0.0062)\end{array}$ & $\begin{array}{c}0.0031 \\
(-0.0135)\end{array}$ \\
\hline $\mathrm{EF}_{4}: \mathrm{FT} \times \mathrm{APAC}$ & $\begin{array}{c}0.0126 \\
(-0.0239)\end{array}$ & $\begin{array}{c}0.0264 * \\
(-0.0148)\end{array}$ & $\begin{array}{c}0.0047 \\
(-0.0087)\end{array}$ & $\begin{array}{c}-0.0157 \\
(-0.0191)\end{array}$ \\
\hline $\mathrm{EF}_{5}: \mathrm{RE} \times \mathrm{APAC}$ & $\begin{array}{c}0.0268 \\
(-0.0305)\end{array}$ & $\begin{array}{l}0.0489 * * \\
(-0.0189)\end{array}$ & $\begin{array}{c}0.0649 * * * \\
(-0.0111)\end{array}$ & $\begin{array}{c}-0.0126 \\
(-0.0244)\end{array}$ \\
\hline Sub-period 1985-1989 & $\begin{array}{c}0.0612 * \\
(-0.0332)\end{array}$ & $\begin{array}{c}0.0113 \\
(-0.0206)\end{array}$ & $\begin{array}{c}0.0565 * * * \\
(-0.0121)\end{array}$ & $\begin{array}{c}-0.0604 * * \\
(-0.0266)\end{array}$ \\
\hline Sub-period 1990-1994 & $\begin{array}{c}0.1431 * * * \\
(-0.0393)\end{array}$ & $\begin{array}{c}0.0318 \\
(-0.0244)\end{array}$ & $\begin{array}{c}0.0896 * * * \\
(-0.0144)\end{array}$ & $\begin{array}{c}-0.0870 * * * \\
(-0.0314)\end{array}$ \\
\hline Sub-period 1995-1999 & $\begin{array}{c}0.2577 * * * \\
(-0.0444)\end{array}$ & $\begin{array}{l}0.0489 * \\
(-0.0276)\end{array}$ & $\begin{array}{c}0.1318^{* * * *} \\
(-0.0162)\end{array}$ & $\begin{array}{c}-0.0753 * * \\
(-0.0355)\end{array}$ \\
\hline Sub-period 2000-2003 & $\begin{array}{c}0.3349 * * * \\
(-0.048)\end{array}$ & $\begin{array}{c}0.0429 \\
(-0.0298)\end{array}$ & $\begin{array}{c}0.1594 * * * \\
(-0.0175)\end{array}$ & $\begin{array}{c}-0.0365 \\
(-0.0384)\end{array}$ \\
\hline Sub-period 2004-2007 & $\begin{array}{c}0.4828 * * * \\
(-0.0485)\end{array}$ & $\begin{array}{c}0.0945 * * * \\
(-0.0301)\end{array}$ & $\begin{array}{c}0.1773 * * * \\
(-0.0177)\end{array}$ & $\begin{array}{c}-0.0061 \\
(-0.0387)\end{array}$ \\
\hline Sub-period 2008-2011 & $\begin{array}{c}0.5915 * * * \\
(-0.0481)\end{array}$ & $\begin{array}{c}0.1654 * * * \\
(-0.0299)\end{array}$ & $\begin{array}{c}0.1998 * * * \\
(-0.0176)\end{array}$ & $\begin{array}{c}-0.0365 \\
(-0.0384)\end{array}$ \\
\hline Sub-period 2012-2014 & $\begin{array}{c}0.7011 * * * \\
(-0.0496)\end{array}$ & $\begin{array}{c}0.2107 * * * \\
(-0.0308)\end{array}$ & $\begin{array}{c}0.2206 * * * \\
(-0.0181)\end{array}$ & $\begin{array}{l}-0.0385 \\
(-0.0397)\end{array}$ \\
\hline Sub-period 2015-2017 & $\begin{array}{c}0.7437 * * * \\
\quad(-0.05)\end{array}$ & $\begin{array}{c}0.2551 * * * \\
(-0.0311)\end{array}$ & $\begin{array}{c}0.2428 * * * \\
(-0.0183)\end{array}$ & $\begin{array}{c}-0.0339 \\
(-0.04)\end{array}$ \\
\hline Constant & $\begin{array}{c}9.8058 * * * \\
(-0.1589) \\
\end{array}$ & $\begin{array}{c}0.5515^{* * *} \\
(-0.0987) \\
\end{array}$ & $\begin{array}{c}0.8400 * * * \\
(-0.0581) \\
\end{array}$ & $\begin{array}{c}-0.4718^{* * *} \\
(-0.1269) \\
\end{array}$ \\
\hline Within- $\mathrm{R}^{2}$ & 0.8586 & 0.6526 & 0.8 & 0.1471 \\
\hline \# Observations & 288 & 288 & 288 & 288 \\
\hline $\begin{array}{l}\text { \# Countries } \\
\text { Period dummies } \mathrm{F}(8,238)\end{array}$ & 32 & 32 & 32 & 32 \\
\hline p-value & 0.0000 & 0.0000 & 0.0000 & 0.0399 \\
\hline Friedman's Cross Sectional Independence & 8.117 & 2.183 & 5.725 & 2.825 \\
\hline Hausman Test p-value & 0.0000 & 0.0000 & 0.0000 & 0.0040 \\
\hline
\end{tabular}

Notes: $* * * 1 \%, * * 5 \%, * 10 \%$. Standard errors in parentheses. 
Intuitively, these results indicate that in the group of APAC countries, lower public consumption and expenditure, reduction of tariff and non-tariff barriers, less control on the international flow of capital and movement of people raise a country's output per worker. Additionally, tighter monetary policy reduces output per worker and a stronger property rights and rule of law (represented through an impartial judiciary system that guarantees the enforcement of legal contracts), and a greater deregulation of credit, labor and business market operations have statistical insignificant impacts on output per worker.

Table 8: Total Effect of the Components of Economic Freedom on the output per worker, capital intensity, human capital, and total factor productivity in APAC countries

\begin{tabular}{lcccc}
\hline & $\begin{array}{c}\ln y \\
(1)\end{array}$ & $\begin{array}{c}\alpha /(1-\alpha)] \ln k \\
(2)\end{array}$ & $\begin{array}{c}\ln h \\
(3)\end{array}$ & $\begin{array}{c}\ln A \\
(4)\end{array}$ \\
\hline $\mathrm{EF}_{1}$ : Size of Government (SG) & $0.0510^{* *}$ & $-0.0288^{*}$ & 0.0077 & $0.0495^{* *}$ \\
& $(0.0103)$ & $(0.0636)$ & $(0.6086)$ & $(0.0154)$ \\
$\mathrm{EF}_{2}$ : Legal System (LS) & 0.018 & 0.019 & -0.004 & 0.017 \\
& $(0.025)$ & $(0.015)$ & $(0.009)$ & $(0.020)$ \\
$\mathrm{EF}_{3}$ : Sound of Money (SM) & $-0.029^{* *}$ & $-0.012^{*}$, & $-0.016^{* * *}$ & -0.056 \\
& $(0.012)$ & $(0.007)$ & $(0.004)$ & $(0.010)$ \\
$\mathrm{EF}_{4}$ : Freedom to Trade Internationally (FT) & $0.040^{* *}$ & $0.017^{*}$, & $0.014^{* *}$ & 0.005 \\
& $(0.017)$ & $(0.011)$ & $(0.006)$ & $(0.014)$ \\
$\mathrm{EF}_{5}$ : Regulation (RE) & -0.013 & $0.0324^{* *}$ & $0.048^{* * *}$ & $-0.035^{*}$ \\
& $(0.026)$ & $(0.016)$ & $(0.009)$ & $(0.021)$ \\
\hline \hline
\end{tabular}

Notes: $* * * 1 \%,{ }^{* *} 5 \%, * 10 \%$, and ${ }^{*} 15 \%$. In parentheses we present the standard error to the total effect of adding up the coefficient of EF to the interaction between this coefficient and a regional dummy variable that takes the value 1 for APAC countries (i.e., $\mathrm{EF}_{\mathrm{j}} \times \mathrm{APAC}$ ). (The coefficients are taken from the results of the previous table)

To analyze the channel through which the different areas of economic freedom affect output per worker, columns (2) to (4) present the results of the total effects of each area. The results indicate that a ten percent increase in the size of the government index increases output per worker by about $0.51 \%$ and this is mainly through increasing the country's total factor productivity by about $0.50 \%$ and lowering its capital intensity by about $0.29 \%$. Since the coefficient associated to total factor productivity outweighs the coefficient on capital intensity $(0.50 \%$ and $-0.30 \%$, respectively), the net effect on output per worker is positive.

Similarly, the channel through which a tight monetary policy lowers output per workers is by lowering its capital intensity and human capital accumulation. More 
specifically, a ten percent increase in a country's sound of money sub-index leads to a decrease in output per worker by about $0.29 \%$ mainly derived from lowering capital intensity and human capital accumulation by about $0.12 \%$ and $0.16 \%$, respectively. These results goes in line with the results of Alexandrakis and Livanis (2013) and Emara and Rebolledo (2019) and with what we expect from the Fisher's Effect discussed in Mundell (1963) and Tobin (1965). In addition, the results show that a ten percent increase in the freedom to trade index increases output per worker by about $0.4 \%$ and this is mainly through increasing the country's capital intensity by about $0.17 \%$ and human capital accumulation by about $0.14 \%$. This result is line with Irwin and Tervio (2002), Frankel and Romer (1999), Lee, Ricci, and Rigobon (2004), Barkhordari, Fattahi, and Azimi (2019), among others, who confirmed that trade openness is significantly contributing to economic growth. Additionally, this goes well with the study of the World Bank (1993) that shows that engagement in the international economy by the East Asian countries was their main source of economic growth.

Although the effect of (de) regulation does not have a significant effect on output per worker, it has a positive and statistically significant effect on a country's capital intensity and human capital accumulation, but a negative one on total factor productivity. Finally, our results indicate that property rights and rule of law do not show a statistically significant effect on either output per worker or its three components in the APAC region.

In the final part of the analysis, we analyze how better levels of governance affects the impact of economic freedom on economic performance. Table 9 shows the results of computing the total effect of economic freedom when interacted with the governance index. The results suggest that economic freedom in the presence of better governance has a positive and statistically significant impact on output per worker and its three alternative measures; capital intensity, human capital accumulation, and total factor productivity. What's more, the results show that the presence of good institutions magnifies the impact of economic freedom by about 5.2 folds, where a one percent increase in the economic freedom index increases output per worker by about $0.31 \%$ (compared with 0.0583 in Table 4). Similarly, our results indicate that improved levels of governance boost the impact of economic freedom on both capital intensity and human capital accumulation by around 1.5 and 2.15 folds, respectively. The results show that a 
one percent increase in the economic freedom index increases both variables by around $0.047 \%$ and $0.045 \%$, respectively. Additionally, the presence of better governance enhances the impact of economic freedom on total factor productivity. A one percent increase in economic freedom index when coupled with better governance increases total factor productivity by about $0.1 \%$. It is important to note that this effect was insignificant without the interaction with the governance indicator, as indicated on Table 4 . The results are in line with the findings of Banerji and Humphreys (2003), Emara and Johnsa (2014), and Emara and Chiu (2016) who found that good institutional quality improves economic performance. Table 10 shows how the four dimensions of governance including the control of corruption, government effectiveness, political stability, and voice and accountability improve the impact of economic freedom on output per worker and its three alternative measures.

Table 9: Total Effect of Economic Freedom and Governance on the output per worker, capital intensity, human capital, and total factor productivity - Full Sample

\begin{tabular}{ccccc}
\hline & $\ln y$ & {$[\alpha /(1-\alpha)] \ln k$} & $\ln h$ & $\ln A$ \\
& $(1)$ & $(2)$ & $(3)$ & $(4)$ \\
\hline EF: Economic Freedom and Governance & $.305^{* * *}$ & $.047^{*}$ & $0.045^{* * *}$ & $0.096^{* *}$ \\
& $(0.051)$ & $(0.034)$ & $(0.015)$ & $(.042)$
\end{tabular}

Notes: $* * * 1 \%, * * 5 \%, * 10 \%$. In parentheses we present the standard error to the total effect of adding up the coefficient of $\mathrm{EF}$ to the interaction between this coefficient and the governance indicator (i.e., EF $\times$ Governance).

Table 10: Total Effect of Economic Freedom and Governance Dimensions on the output per worker, capital intensity, human capital, and total factor productivity - Full Sample

\begin{tabular}{lcccc}
\hline & $\ln y$ & {$[\alpha /(1-\alpha)] \ln k$} & $\ln h$ & $\ln A$ \\
& $(1)$ & $(2)$ & $(3)$ & $(4)$ \\
\hline EF: Economic Freedom \& Corruption & $.350^{* * *}$ & 0.032 & $0.039^{* *}$ & $0.132^{* * *}$ \\
& $(0.051)$ & $(0.034)$ & $(0.015)$ & $(.043)$ \\
EF: Economic Freedom \& Government & & & & \\
$\quad$ Effectiveness & $.351^{* * *}$ & $0.067^{*}$ & $0.026^{*}$ & $0.112^{* *}$ \\
& $(0.055)$ & $(0.036)$ & $(0.012)$ & $(.046)$ \\
& $.313^{* * *}$ & 0.018 & $0.019 *$ & $0.127^{* * *}$ \\
EF: Economic Freedom \& Political Stability & $(0.039)$ & $(0.026)$ & $(0.012)$ & $(.032)$ \\
& $.326^{* * *}$ & 0.018 & $0.033^{* * *}$ & $0.131^{* * *}$ \\
EF: Economic Freedom \& Accountability & $(0.039)$ & $(0.026)$ & $(0.011)$ & $(.033)$ \\
\hline
\end{tabular}

Notes: $* * * 1 \%, * * 5 \%, * 10 \%$. In parentheses we present the standard error of the total effect of adding up the coefficient of $\mathrm{EF}$ to its interaction with the chosen governance indicator (i.e., $\mathrm{EF} \times$ Governance).

Since the majority of the APAC countries in our sample fall below the average of the governance indicator of our sample as shown in Figure (4), the remaining governance 
analysis is focused on the APAC region. The objective is to further analyze how improved institutions can affect the impact of economic freedom on economic performance; Table (11) shows the results when the dummy variable for the APAC region is interacted with the governance index and with the economic freedom index.

Figure (4): Governance Index and Output per Worker, (Average of the period 2015 - 2017)

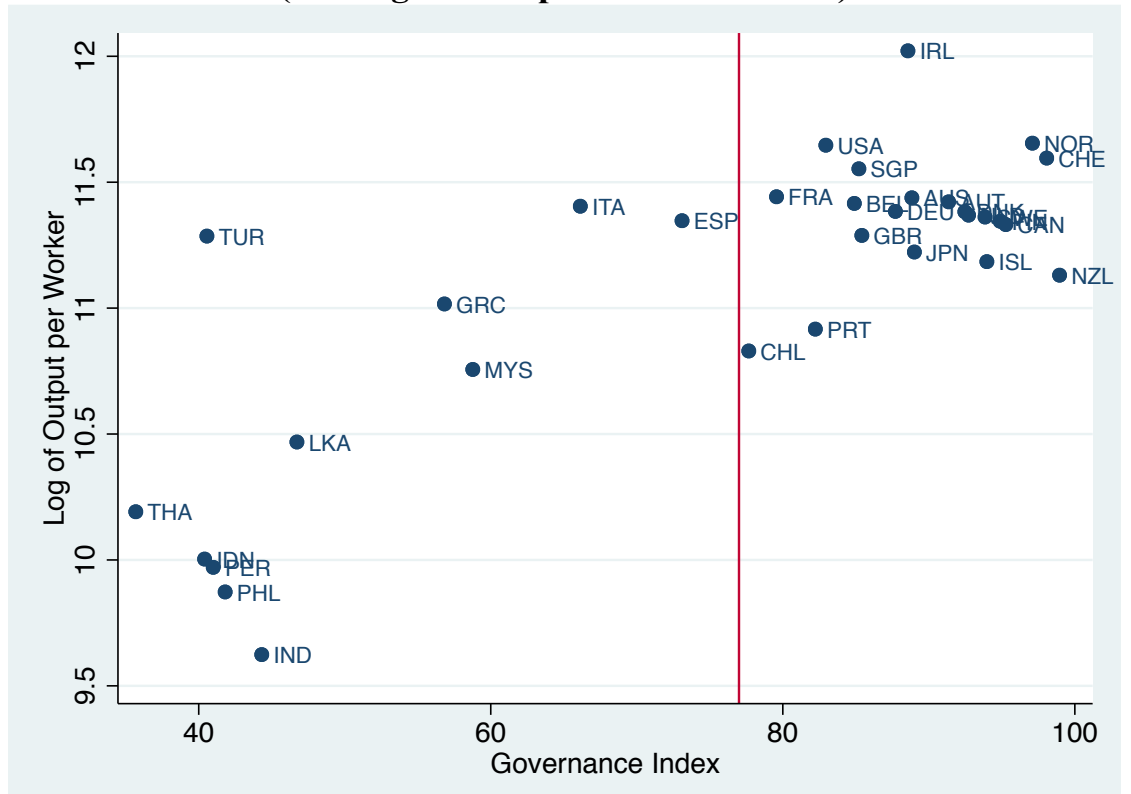

Source: Author computation.

Note: The red line corresponds to the mean of the governance index of 76.53 points.

The results of Table 11 show a positive and statistically significant impact of the aggregated index for economic freedom where a one percent increase in this index leads to an increase in output per worker by about $0.32 \%$ for the APAC countries, which is gain around five folds the impact of economic freedom without the presence of good institutions (compared with 0.06 in Table 6). Results in columns (2) to (4) suggest the main channel that explains this relationship is through human capital accumulation and total factor productivity, where a one percent increase in the economic freedom index leads to $0.025 \%$ and $0.17 \%$ increase in human capital accumulation and total factor productivity, respectively. It is interesting to note that the channel of capital intensity when interacted with governance is statistically insignificant and the channel of total factor productivity is only significant when interacted with good governance. 
Table 11: Total Effect of Economic Freedom and Governance on the output per worker, capital intensity, human capital, and total factor productivity - APAC Countries

\begin{tabular}{ccccc}
\hline & $\ln y$ & {$[\alpha /(1-\alpha)] \ln k$} & $\ln h$ & $\ln A$ \\
& $(1)$ & $(2)$ & $(3)$ & $(4)$ \\
\hline EF: Economic Freedom and Governance & $.322^{* * *}$ & -0.019 & $0.025^{* *}$ & $0.170^{* * *}$ \\
& $(0.051)$ & $(0.025)$ & $(0.015)$ & $(.042)$ \\
\hline
\end{tabular}

Notes: $* * * 1 \%, * * 5 \%, * 10 \%$. In parentheses we present the standard error to the total effect of adding up the coefficient of $\mathrm{EF}$ to the interaction between this coefficient and a regional dummy variable that takes the value 1 for $\mathrm{APAC}$ countries and the governance indicator (i.e., $\mathrm{EF} \times \mathrm{APAC} \times$ Governance).

Finally, analyze the channel through which the different areas of economic freedom affect output per worker in the APAC region in the presence of good levels of governance. Table 12 presents the results of the total effects of each area of economic freedom is interacted with the governance indicator. The results indicate that a ten percent increase in the size of the government index increases output per worker by about $0.60 \%$ and this is mainly through increasing the country's total factor productivity by about $0.48 \%$ and lowering its capital intensity by about $0.39 \%$. Since the coefficient associated to total factor productivity outweighs the coefficient on capital intensity $(0.48 \%$ and $-0.39 \%$, respectively), the net effect on output per worker is positive.

Table 12: Total Effect of the Components of Economic Freedom and Governance on the output per worker, capital intensity, human capital, and total factor productivity in APAC countries

\begin{tabular}{lcccc} 
& $\begin{array}{c}\ln y \\
(1)\end{array}$ & $\begin{array}{c}\alpha /(1-\alpha)] \ln k \\
(2)\end{array}$ & $\begin{array}{c}\ln h \\
(3)\end{array}$ & $\begin{array}{c}\ln A \\
(4)\end{array}$ \\
\hline $\mathrm{EF}_{1}$ : Size of Government (SG) \& Governance & $0.059^{* *}$ & $-0.039^{* *}$ & 0.0003 & $0.048^{* *}$ \\
& $(0.026)$ & $(0.016)$ & $(0.008)$ & $(0.021)$ \\
& $0.082^{* *}$ & 0.025 & -0.008 & 0.004 \\
$\mathrm{EF}_{2}$ : Legal System (LS) \& Governance & $(0.034)$ & $(0.021)$ & $(0.010)$ & $(0.028)$ \\
& $0.053^{* * *}$ & $-0.019^{*}$ & 0.006 & 0.007 \\
$\mathrm{EF}_{3}$ : Sound of Money (SM) \& Governance & $(0.016)$ & $(0.010)$ & $(0.005)$ & $(0.013)$ \\
& & & & \\
$\mathrm{EF}_{4}$ : Freedom to Trade Internationally (FT) \& & $0.121^{* * *}$ & $-0.046^{* *}$ & $0.024^{* *}$ & $0.124^{* * *}$ \\
$\mathrm{Governance}$ & $(0.033)$ & $(0.020)$ & $(0.010)$ & $(0.026)$ \\
$\mathrm{EF}_{5}$ : Regulation (RE) \& Governance & 0.020 & -0.0037 & -0.0018 & 0.010 \\
& $(0.028)$ & $(0.017)$ & $(0.008)$ & $(0.023)$ \\
\hline \hline
\end{tabular}

Notes: $* * * 1 \%, * * 5 \%, * 10 \%$. In parentheses we present the standard error to the total effect of adding up the coefficient of the EF to the interaction between this coefficient and a regional dummy variable that takes the value 1 for APAC countries and the governance indicator (i.e., $\mathrm{EF} \times \mathrm{APAC} \times$ Governance).

It is interesting to note that the impact of a strong legal system on output per worker in the APAC region is only significant in the presence of better governance, 
where a ten percent increase in country's legal system sub-index increases output per worker by about $0.82 \%$. However the channel through which this effect works is not clear from the results since all the three channels are statistically insignificant. Similarly, our results indicate that good governance does not improve the impact of (de) regulations on output per worker or its three alternative measures, where the four coefficients are statistically insignificant.

Furthermore, the results indicate that better levels of governance amplifies the positive impact of a tight monetary policy, represented by low and stable inflation, on output per worker, where a ten percent increase in the country's sound of money index increases output per worker by about $0.53 \%$, which is mainly driven by a fall in capital intensity by about $0.19 \%$. This result is in line with empirical evidence provided in Emara (2012), where strong institutions reduce the negative impact of inflation volatility on economic growth. Additional empirical support is provided in the study of Yilmazkuday (2010) who finds that low inflation increases economic growth in countries with strong institutions but it reduces it in countries with weak institutions.

One of the evident impacts of good governance is shown in how it improves the impact of a country's freedom to trade on economic performance. Our results indicate that a ten percent increase in country's freedom to trade increases output per worker by about $0.12 \%$. Thus, better governance amplifies the impact of international trade by about three folds $(0.121$ versus 0.04$)$. This result supports the empirical evidence provided by Groot, H., Linders, G., and Rietveld, P. (2009) who showed that governance matters to international trade and is in line with a pool of research on how corporate governance is a precondition for product competition in international markets (Karuna 2007, Giroud and Mueller 2010, Kadyrzhanova and Rhodes-Kropf 2011, Chhaochharia et al. 2013). Finally, the table shows that this positive impact on output per worker is mainly driven by about $0.24 \%$ increase in the country's human capital accumulation, $0.12 \%$ enhancement in total factor productivity, and about $0.05 \%$ reduction in its capital intensity. Since the coefficients associated to human capital accumulation and total factor productivity outweighs the coefficient on capital intensity $(0.24 \%$ and $0.12 \%$ versus $-0.05 \%$, respectively), the net effect on output per worker is positive. 


\section{Conclusions}

The link between the improvement in measures of economic freedom on economic performance and the impact of good governance on such a link has been understudied.

Given the importance of this relationship, the study contributes to the literature by filling the gaps and analyzing the effect of a country's economic freedom on its economic performance for sample of 14 countries of the APAC region and 18 OECD countries over the period 1980-2017. Using panel least squares with fixed effects estimation methodology, the study contributes to the literature by confirming that governance is a prerequisite in this link; where better governance quality amplifies the impact of economic freedom on output per worker in the full sample, OECD, and APAC region.

More specifically, for our full sample, the results suggest that economic freedom has a positive impact on output per worker by improving capital intensity and human capital accumulation. Additionally, the positive impact of economic freedom on output per worker is amplified by about five folds in the presence of good governance quality. The results also show that the impact of economic freedom on a country's total factor productivity is only statistically significant in the presence of good governance quality.

Distinguishing the sample between OECD and APAC countries, we find that the effect of a country's economic on its output per worker is positive and statistically significant, but the magnitude of the effect is lower for OECD than for APAC countries. Additionally, and in line with Emara and Rebolledo (2019), we find evidence that in OECD countries this effect is mainly driven by an improvement in total factor productivity and by an improvement in capital intensity and human capital accumulation for the APAC region.

In exploring the channels through which the five economic freedom sub-indices affect output per worker, our results show that a smaller government (represented through a lower public consumption and expenditure) raises output per worker in both OECD and the APAC region. Stronger property rights (represented through an impartial judiciary system that guarantees the enforcement of legal contracts), and greater deregulation of credit, labor and business market operations, also raise output per worker in OECD but not in APAC. A tighter monetary policy (represented through a lower and more stable 
inflation) reduces output per worker in the APAC region through reducing capital intensity and human capital accumulation but increases the same variables in the OECD. Freedom to access international markets also raise output per worker in the APAC though the increase of capital intensity and human capital accumulation and through the latter in the OECD region. Finally, in the OECD countries a greater deregulation of credit, labor and business market operations is insignificantly affecting output per worker in the APAC region but has a statistical significant impact on this variable in the OECD countries which is mainly derived from the increase in human capital accumulation.

Finally, the results indicate that different areas of economic freedom affect the groups of countries differently depending on their level of development and governance preparedness. More specifically, we find that governance matters more for the APAC than for the OECD countries. For the APAC region, governance is proved to amplify the positive impact of economic freedom on output per worker, capital intensity, and human capital accumulation by about five, one and half, and two folds, respectively. Additionally, it is only in the presence of good governance quality that a tight monetary policy and a strong legal system statistically significantly increase output per worker. And it is only with good governance that the freedom to trade internationally significantly affects a country's total factor productivity.

Thus, policy makers should design economic growth policies that complements measures of economic freedom with good quality of governance; our results indicate that the positive impact of economic freedom on economic performance is magnified when complemented with the freedom of a country's citizens in selecting governments and expressing their political views, political stability, enhanced quality of public services, and control of corruption. 


\section{References}

Akcay, S. (2006). Corruption and human development, Cato Journal, 25 (1), pp. 25-27.

Altman, M. (2008). How much Economic Freedom is Necessary for Economic Growth? Theory and Evidence. Economics Buletin, 15(2), 1-20.

Brito-Bigott, O., Faria, H.J., Rodriguez, J.M., \& Sanchez, A. (2008). Corruption and complex business rules, Journal of Private Enterprise, 24 (1), pp. 1-15.

Alexandrakis, Constantine and Livanis, Grigorios. (2013). Economic Freedom and Economic Performance in Latin America: A Panel Data Analysis. Review of Development Economics, 17(1): 34-48.

Barro, R.J. (1997). Determinants of economic growth: a cross-country empirical study, Cambridge, MA, M.I.T. Press.

Barkhordari, S., Fattahi, M., Azimi, N.A. (2019), The Impact of Knowledge-Based Economy on Growth Performance: Evidence from MENA Countries. Journal of the Knowledge Economy, 10, 1168-1182. https://doi.org/10.1007/s13132-018-0522-4

Berggren, N. (2003). The Benefits of Economic Freedom: A Survey. The Independent Review, 8(2), 193-211.

Bjørnskov, Christian (2008). The growth-inequality association: Government ideology matters. Journal of Development Economics, 87, 300-38.

Boockmann, B. and A. Dreher (2002). The contribution of the IMF and the World Bank to economic freedom. European Journal of Political Economy, 19, 633-649.

Caudill, S., Zanella, F., and Mixon, F. (2000). Is Economic Freedom One Dimensional ? A Factor Analysis of Some Common Measures of Economic Freedom, Journal of Economic Development, 25(1), 17-40.

Cebula , Richard J. (2011). Economic Growth, Ten Forms of Economic Freedom and Political Stability: An Empirical Study Using Panel Data, 2003-2007. The Journal of Private Enterprise, 26(2), 61-81.

Chhaochharia V., Grinstein Y., Grullon G. and Michaely R. 2013. "Product Market Competition and Internal Governance: Evidence from the Sarbanes Oxley Act", working paper. DOI:10.1287/mnsc.2015.2409.

Corbi, Raphael B (2007). The Components of Economic Freedom, Income, and Growth: An Empirial Analysis. Estudos Econômicos (São Paulo), 37(3), 515-545.

Cebula, Richard J., Clark J.R., and Mixon Franklin G. (2012). The Impact of Economic Freedom on Per Capital Real GDP: A Study of OECD Nations. The Journal of Regional Analysis and Policy, 43(1), 34-41. 
D’Agostino, Giorgio, Dunne J. Paul, and Pieroni Luca (2016). Government Spending, Corruption and Economic Growth. World Development, 84, 190-205.

De Haan, J., \& Siermann, C.L.J. (1998). Further evidence on the relationship between economic freedom and economic growth, Public Choice, 95 (4), pp. 363-380.

De Haan, J., \& Sturm, J.E. (2000). On the relationship between economic freedom and economic growth, European Journal of Political Economy, 16 (2), pp. 215-241.

Emara, Noha (2012). Inflation Volatility, Institutions, and Economic Growth, Global Journal of Emerging Market Economies, 4(1): 29-53.

Emara, Noha (2014). Quantitative Evaluation of the Struggle of Economic Performance: The Case of MENA Countries, Topics in Middle Eastern and African Economies, 16(2): 184-190.

Emara, N. (2016). Economic Freedom and Economic Performance: The Case MENA Countries. The Journal of Middle East North Africa Sciences, 2(2), 1-15.

Emara, N., \& Chiu, I. (2016). The Impact of Governance Environment on Economic Growth: The Case of Middle Eastern and North African Countries, 2016, Journal of Economics Library, 3(1), 24-37.

Emara, N., and El Said, A. (2020). Financial Inclusion and Economic Growth: The Role of Governance in Selected MENA Countries, MPRA Paper 99257, University Library of Munich, Germany.

Emara, N., \& Jhonsa, E. (2014). Governance and Economic Growth: The Case of Middle East and North African Countries, 2014, Journal of Development and Economic Policies, 16(1), 47-71.

Emara, N., and Moheildin, M. (2020). Financial Inclusion and Extreme Poverty: The Role of Governance: A Gap Analysis Approach. Review of Economics and Political Science, $5(2)$.

Emara, N. and Rebolledo, L. (2019). On the Relationship Between Economic Freedom and Output Per Worker: The Case of Asia-Pacific Countries, International Journal of Economics and Financial Issues, 9(6), 184-194.

Frankel, J.A., and D. Romer. 1999. Does trade cause growth? American Economic Review 89 (3): 379-399.

Fraser Institute. Economic Freedom Index 1980-2018. Retrieved from this link.

Giroud X. and Mueller H. 2010. "Does Corporate Governance Matter in Competitive Industries?" Journal of Financial Economics 95, 312-331.

Groot, H., Linders, G., and Rietveld, P. (2009). Institutions, Governance and International Trade: Opening the Black Box of OECD and GDP per Capita Effects in Gravity Equations, IATSS Research, Volume 29, Issue 2, 2005, Pages 22-29 
Gwartney, J., Holcombe, R., and Lawson, R. (2004). Economic Freedom, Institutional Quality, and Cross-Country Differences in Income and Growth, CATO Journal, 24(3), 205-233.

Haan Jakob D. and Sturm, Jan-Egbert. (1999). On the relationship between Economic Freedom and Economic Growth. University of Groningen. s.n. Retrieved from this link.

Hall, Robert and Jones, Charles I. (1999). Why Do Some Countries Produce So Much More Output Per Worker Than Others? Quarterly Journal of Economics, 114: 83-116.

Heckelman, Jac C. and Stroup Michael D. (2000). Which Economic Freedoms Contribute to Growth? KYKLOS, 53(4), 527-544.

Heckelman, Jac C. (2000). Economic Freedom and Economic Growth: A Short-run Causal Intestigation. Journal of Applied Economics, 3(1), 71-91.

Irwin, D.A., and M. Terviö. 2002. Does trade raise income? Evidence from the twentieth century. Journal of International Economics 58 (1), 1-18.

Karuna, C. 2007. "Industry Product Market Competition and Managerial Incentives", Journal of Accounting and Economics 43, 275-297.

Kadyrzhanova D. and Rhodes-Kropf M. 2011. "Concentrating on Governance", Journal of Finance 66, 1649-1685.

Lajili, O. and Gilles, P. (2018). Financial liberalization, political openness and growth in developing countries: Relationship and transmission channels, Journal of Economic Development, 43(1), 1-27.

Lee, H.Y., L.A. Ricci, and R. Rigobon. 2004. Once again, is openness good for growth? Journal of Development Economics 75: 451-472.

$\mathrm{Li}, \mathrm{Pei}, \mathrm{Lu} \mathrm{Yi}$, and Wang Jin (2016). Does flattening government improve economic performance? Evidence from China, Journal of Development Economics 123: 18-37.

Miller, T. and A.B. Kim (2017). 2017 Index of Economic Freedom. The Heritage Foundation. Retrieved from this link.

Moral, E., Gan, V. (2018) Economic freedom, good governance and the dynamics of development, Journal of Applied Economics, 21 (1), 44-66.

Romer, Christina D. and David H. Romer, A New Measure of Monetary Shocks: Derivation and Implications, American Economic Review, 94 (2004):1055-84.

Santacreu, A. M. (2017). How Does U.S. Income Inequality Compare Worldwide? Federal Reserve Bank of St.Louis. Retrieved from this link.

Yilmazkuday, H. (2019). Inflation and Growth: The Role of Institutions. Available at SSRN: https://ssrn.com/abstract=3503569 or http://dx.doi.org/10.2139/ssrn.3503569. 
The International Monetary Fund (IMF) (2020). Retrieved from this link.

The Organisation for Economic Co-operation and Development (OECD) (2020). Retrieved from this link.

The World Bank (2020). What We Do. Retrieved from this link.

World Bank (1993). The East Asian Miracle. Policy Research Report. ISSN 1020-0851. 
APPENDIX

Table A1: List of OECD included in the Sample

\begin{tabular}{|c|l|l|}
\hline Country ID & Country & Code \\
\hline 1 & Austria & AUT \\
\hline 2 & Belgium & BEL \\
\hline 3 & Denmark & DNK \\
\hline 4 & Finland & FIN \\
\hline 5 & France & FRA \\
\hline 6 & Germany & DEU \\
\hline 7 & Greece & GRC \\
\hline 8 & Iceland & ISL \\
\hline 9 & Ireland & IRL \\
\hline 10 & Italy & ITA \\
\hline 11 & Netherlands & NLD \\
\hline 12 & Norway & NOR \\
\hline 13 & Portugal & PRT \\
\hline 14 & Spain & ESP \\
\hline 15 & Sweden & SWE \\
\hline 16 & Switzerland & CHE \\
\hline 17 & Turkey & TUR \\
\hline 18 & United Kingdom & GBR \\
\hline
\end{tabular}

Table A2: List of APAC included in the Sample

\begin{tabular}{|c|l|l|}
\hline Country ID & Country & Code \\
\hline 1 & Australia & AUS \\
\hline 2 & Canada & CAN \\
\hline 3 & Chile & CHL \\
\hline 4 & India & IND \\
\hline 5 & Indonesia & IDN \\
\hline 6 & Japan & JPN \\
\hline 7 & Malaysia & MYS \\
\hline 8 & New Zealand & NZL \\
\hline 9 & Peru & PER \\
\hline 10 & Philippines & PHL \\
\hline 11 & Singapore & SGP \\
\hline 12 & Sri Lanka & LKA \\
\hline 13 & Thailand & THA \\
\hline 14 & United States & USA \\
\hline
\end{tabular}


Table A3: Description of Sample Sub-periods

\begin{tabular}{|c|c|c|c|c|}
\hline Year & Sub-period & $\begin{array}{l}\text { Length of Sub- } \\
\text { period (No. years) }\end{array}$ & $\begin{array}{l}\text { Economic } \\
\text { Freedom } \\
\text { Index }^{(a)}\end{array}$ & $\begin{array}{l}\text { Dependent } \\
\text { Variables }^{(b)}\end{array}$ \\
\hline 1980 & \multirow{5}{*}{ 1980-1984 } & \multirow{5}{*}{5} & \multirow{5}{*}{1980} & \multirow{5}{*}{ Average 1980-1984 } \\
\hline 1981 & & & & \\
\hline 1982 & & & & \\
\hline 1983 & & & & \\
\hline 1984 & & & & \\
\hline 1985 & \multirow{5}{*}{ 1985-1989 } & \multirow{5}{*}{5} & \multirow{5}{*}{1985} & \multirow{5}{*}{ Average 1985-1989 } \\
\hline 1986 & & & & \\
\hline 1987 & & & & \\
\hline 1988 & & & & \\
\hline 1989 & & & & \\
\hline 1990 & \multirow{5}{*}{ 1990-1994 } & \multirow{5}{*}{5} & \multirow{5}{*}{1990} & \multirow{5}{*}{ Average 1990-1994 } \\
\hline 1991 & & & & \\
\hline 1992 & & & & \\
\hline 1993 & & & & \\
\hline 1994 & & & & \\
\hline 1995 & \multirow{5}{*}{ 1995-1999 } & \multirow{5}{*}{5} & \multirow{5}{*}{1995} & \multirow{5}{*}{ Average 1995-1999 } \\
\hline 1996 & & & & \\
\hline 1997 & & & & \\
\hline 1998 & & & & \\
\hline 1999 & & & & \\
\hline 2000 & \multirow{4}{*}{$2000-2003$} & \multirow{4}{*}{4} & \multirow{4}{*}{2000} & \multirow{4}{*}{ Average $2000-2003$} \\
\hline 2001 & & & & \\
\hline 2002 & & & & \\
\hline 2003 & & & & \\
\hline 2004 & \multirow{4}{*}{ 2004-2007 } & \multirow{4}{*}{4} & \multirow{4}{*}{2004} & \multirow{4}{*}{ Average 2004-2007 } \\
\hline 2005 & & & & \\
\hline 2006 & & & & \\
\hline 2007 & & & & \\
\hline 2008 & \multirow{4}{*}{$2008-2011$} & \multirow{4}{*}{4} & \multirow{4}{*}{2008} & \\
\hline 2009 & & & & $A_{\text {yera }} 2008$ 2011 \\
\hline 2010 & & & & Average $2000-2011$ \\
\hline 2011 & & & & \\
\hline 2012 & & & & \\
\hline 2013 & $2012-2014$ & 3 & 2012 & Average $2012-2014$ \\
\hline 2014 & & & & \\
\hline 2015 & & & & \\
\hline 2016 & 2015-2017 & 3 & 2015 & Average 2015-2017 \\
\hline 2017 & & & & \\
\hline
\end{tabular}

Notes: (a) Economic Freedom Index correspond to the aggregate economic freedom index developed by the Fraser Institute as well as disaggregate index for each one of the five policy areas. (b) Dependent variables correspond to log of: output per worker $(\ln y)$, capital intensity $([\alpha /(1-\alpha)] \ln k)$, human capital accumulation $(\ln h)$, and total factor productivity $(\ln A)$. 


\section{Table A4: Governance Indicators and Definitions}

\begin{tabular}{|l|l|}
\hline \multicolumn{1}{|c|}{ Governance Index } & \multicolumn{1}{c|}{ Definition } \\
\hline $\begin{array}{l}\text { 1- Voice and } \\
\text { accountability }\end{array}$ & $\begin{array}{l}\text { Measured by the extent to which a country's citizens are able to participate in } \\
\text { selecting their government as well as freedom of expression, association, and } \\
\text { the press. }\end{array}$ \\
\hline $\begin{array}{l}\text { 2- Political stability and } \\
\text { absence of violence }\end{array}$ & $\begin{array}{l}\text { Measured by the likelihood that a government will be destabilized by } \\
\text { unconstitutional or violent means, including terrorism. }\end{array}$ \\
\hline $\begin{array}{l}\text { 3- Government } \\
\text { effectiveness }\end{array}$ & $\begin{array}{l}\text { Measured by the quality of public services, the capacity of civil services and } \\
\text { their independence from political pressure, and the quality of policy } \\
\text { formulation. }\end{array}$ \\
\hline 4- Control of corruption & $\begin{array}{l}\text { Measured by the extent to which public power is exercised for private gain, } \\
\text { including both petty and grand forms of corruption as well as elite "capture" } \\
\text { of the state. }\end{array}$ \\
\hline
\end{tabular}

